\title{
CONTACT-HANDLED \\ TRANSURANIC WASTE ACCEPTANCE CRITERIA FOR \\ THE WASTE ISOLATION PILOT PLANT
}

Revision 4.0

Effective Date: December 29, 2005

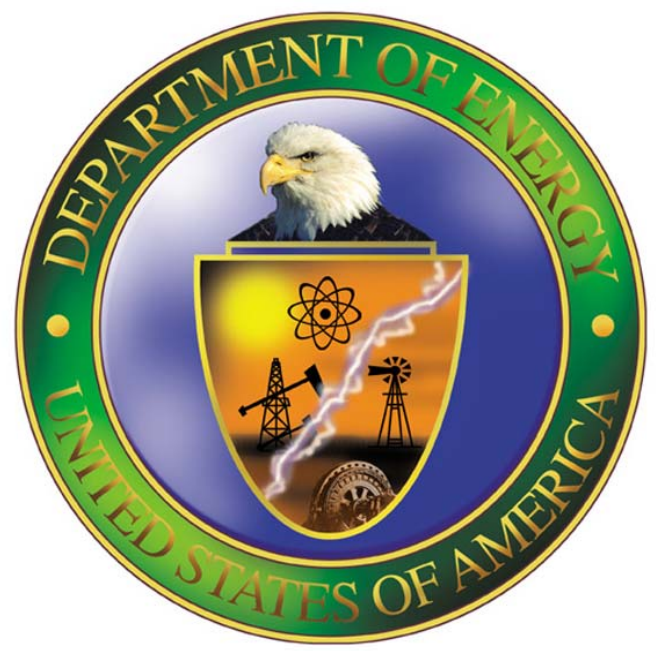

U.S. Department of Energy

Carlsbad Field Office 
This document has been submitted as required to:

Office of Scientific and Technical Information PO Box 62

Oak Ridge, TN 37831

(615) $576-8401$

Additional information about this document may be obtained by calling 1-800-336-9477. Copies may be obtained by contacting the National Technical Information Service, U.S. Department of Commerce, 5285 Port Royal Road, Springfield, VA 22101. 
DOE/WIPP-02-3122

\section{CONTACT-HANDLED TRANSURANIC WASTE ACCEPTANCE CRITERIA FOR THE WASTE ISOLATION PILOT PLANT}

Revision 4.0

Effective Date: December 29, 2005

Approved by: $\frac{\text { Original Signature on File }}{\text { Carlsbad Field Office Manager }}$ Date: December 2, 2005

Concurred by: $\frac{\text { Original Signature on File }}{\text { Director, Office of Characterization and Transportation }}$ Date: December 2, 2005

Prepared by: $\quad$ Original Signature on File Date: December 2, 2005

TRU Waste Certification Work Coordinator, Office of Characterization and Transportation 


\section{TABLE OF CONTENTS}

CHANGE HISTORY $\ldots \ldots \ldots \ldots \ldots \ldots \ldots \ldots \ldots \ldots \ldots \ldots \ldots \ldots \ldots \ldots \ldots$

INDEX OF CURRENT REVISION/CHANGE NUMBER BY PAGE $\ldots \ldots \ldots \ldots \ldots$ viii

LIST OF ACRONYMS AND ABBREVIATIONS $\ldots \ldots \ldots \ldots \ldots \ldots \ldots$ ix

1.0 INTRODUCTION $\ldots \ldots \ldots \ldots \ldots \ldots \ldots \ldots \ldots \ldots \ldots \ldots \ldots \ldots \ldots \ldots \ldots$

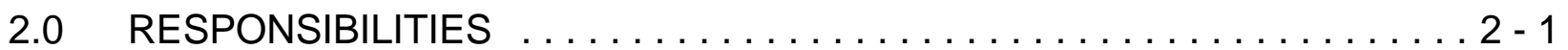

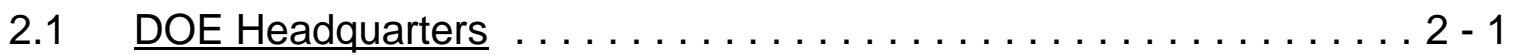

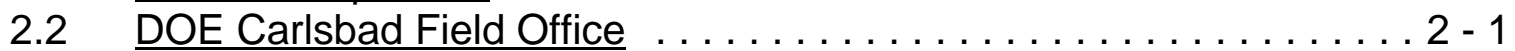

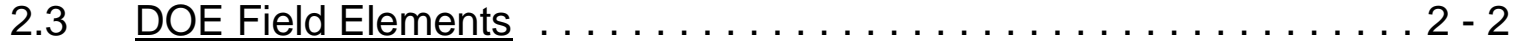

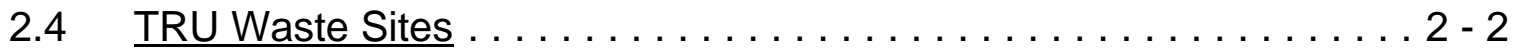

3.0 WIPP WASTE ACCEPTANCE REQUIREMENTS AND CRITERIA . . . . . 3 - 1

3.1 Summary of WIPP Authorization Basis ................ 3 - 1

3.1.1 DOE Operations and Safety Requirements for WIPP . . . . . . 3 - 2

3.1.2 NRC Transportation Safety Requirements ........... 3 - 2

3.1.3 NMED Hazardous Waste Facility Permit Requirements . . . 3 - 3

3.1.4 EPA Requirements ................. 3 - 3

3.1.4.1 EPA Compliance Certification Decision ........ 3 - 3

3.1.4.2 EPA Approval for PCB Disposal ........... 3 - 4

3.1.5 Land Withdrawal Act Requirements ............. 3 - 4

3.1.6 Energy and Water Development Appropriations Act

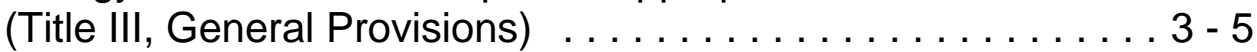

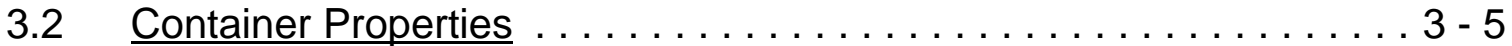

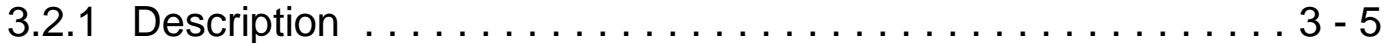

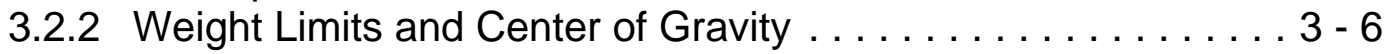

3.2.3 Assembly Configurations ................. 3 - 8

3.2.4 Removable Surface Contamination ............. 3 - 9

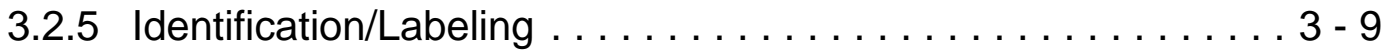

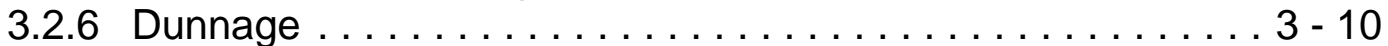

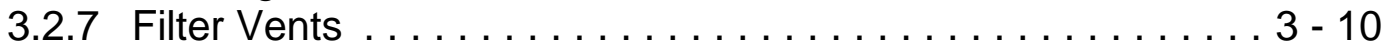

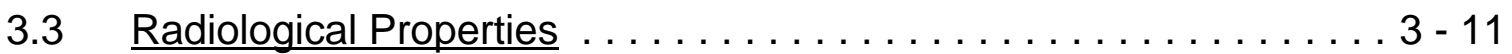

3.3.1 Radionuclide Composition .................. 3 - 11

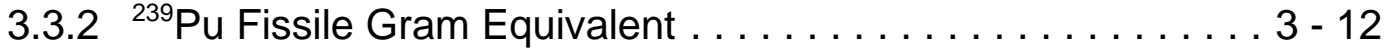

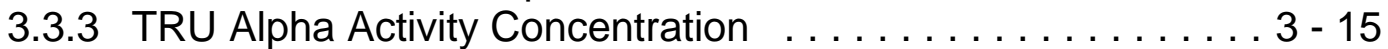

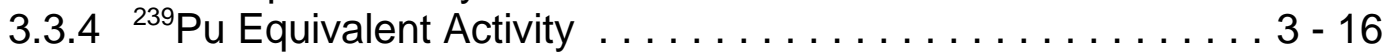

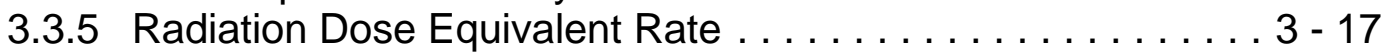

3.3 .6 Decay Heat . . . . . . . . . . . . . . . . . . . 3 - 18

$3.4 \quad$ Physical Properties ........................... 3 - 18

3.4 .1 Residual Liquids $\ldots \ldots \ldots \ldots \ldots \ldots \ldots \ldots \ldots \ldots \ldots \ldots \ldots$ 
3.4.2 Sealed Containers . . . . . . . . . . . . . . . . . . . $3-19$

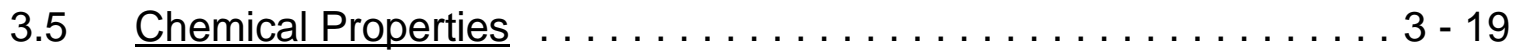

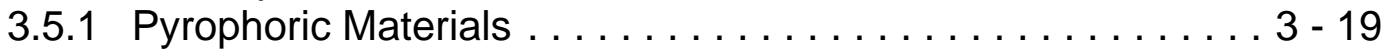

3.5 .2 Hazardous Waste . . . . . . . . . . . . . . . . . . 3 - 19

3.5.3 Chemical Compatibility ..................... 3 - 19

3.5.4 Explosives, Corrosives, and Compressed Gases . . . . . . . . 3 - 20

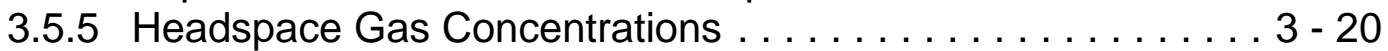

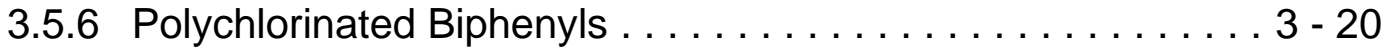

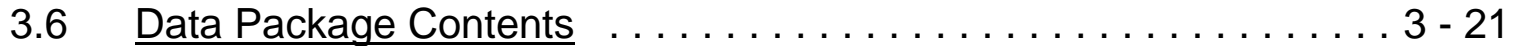

3.6.1 Characterization and Certification Data ............ 3 - 21

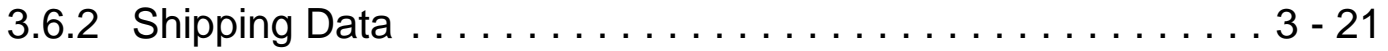

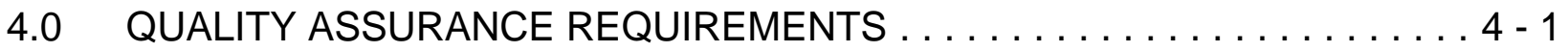

4.1 Waste Characterization Quality Assurance Requirements ....... 4 - 1

4.2 Waste Certification Quality Assurance Requirements . . . . . . . . . 4 - 1

4.3 Waste Transportation Quality Assurance Requirements ......... . 4 - 2

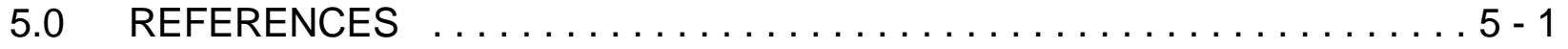

APPENDIX A

Radioassay Requirements for Contact-Handled Transuranic Waste .... . . A - 1

APPENDIX B

${ }^{239} \mathrm{Pu}$ Equivalent Activity $\ldots \ldots \ldots \ldots \ldots \ldots \ldots \ldots \ldots \ldots \ldots \ldots \ldots \ldots \ldots \ldots$

APPENDIX C

Glossary .............................. C 1

APPENDIX D

Payload Container Integrity Checklist $\ldots \ldots \ldots \ldots \ldots \ldots \ldots \ldots \ldots$ D -1

APPENDIX E

Payload Management of TRU Alpha Activity Concentration $\ldots \ldots \ldots \ldots$ E - 1

LIST OF FIGURES

Figure 1.0 Regulatory Basis of $\mathrm{CH}$-TRU Waste Acceptance Criteria . . . . . . 1 - 3

LIST OF TABLES

Table 3.2.2

Weight Limits 
Table 3.2.3.1

TRUPACT-II Payload Assembly Configurations $\ldots \ldots \ldots \ldots \ldots$. . 8

Table 3.2.3.2

HalfPACT Payload Assembly Configurations . . . . . . . . . . . . 3 - 8

Table 3.3.2.1

${ }^{239} \mathrm{Pu}$ FGE Limits for Payload Containers . . . . . . . . . . . . . . . . . . 3 - 12

Table 3.3.2.2

${ }^{239} \mathrm{Pu}$ FGE Limits for Packages $\ldots \ldots \ldots \ldots \ldots \ldots \ldots \ldots \ldots$

Table 3.3.4

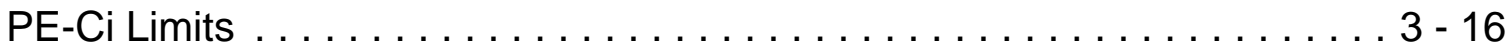

Table A-3

Data Quality Objectives for Radioassay . . . . . . . . . . . . . A - 7

Table A-3.2

Upper Limits for $\%$ RSD vs. Number of Replicates . . . . . . . . . . . . . . A - 10

Table A-4.2

Range of Applicability . . . . . . . . . . . . . . . . . A - 12

Table A-4.3

Quality Control Requirements for Radiochemistry .............. A - 13

Table B-1

PE-Ci Weighting Factors for Selected Radionuclides $\ldots \ldots \ldots \ldots \ldots$. 


\section{CHANGE HISTORY}

DOE/WIPP-02-3122, Revision 0, Effective Date: May 17, 2002, Contact-Handled Transuranic Waste Acceptance Criteria for the Waste Isolation Pilot Plant superceded DOE/WIPP-069, Revision 7, Interim Change Notice \#2, Waste Acceptance Criteria for the Waste Isolation Pilot Plant.

DOE/WIPP-02-3122, Revision 0.1, Effective Date: July 25, 2002, Contact-Handled Transuranic Waste Acceptance Criteria for the Waste Isolation Pilot Plant superceded DOE/WIPP-02-3122, Revision 0.

DOE/WIPP-02-3122, Revision 1, Effective Date: March 1, 2004, Contact-Handled Transuranic Waste Acceptance Criteria for the Waste Isolation Pilot Plant superseded DOE/WIPP-02-3122, Revision 0.1.

DOE/WIPP-02-3122, Revision 2.0, Effective Date: November 15, 2004, ContactHandled Transuranic Waste Acceptance Criteria for the Waste Isolation Pilot Plant superseded DOE/WIPP-02-3122, Revision 1.

DOE/WIPP-02-3122, Revision 2.1, Effective Date: March 19, 2005, Contact-Handled Transuranic Waste Acceptance Criteria for the Waste Isolation Pilot Plant superseded DOE/WIPP-02-3122, Revision 2.0.

DOE/WIPP-02-3122, Revision 3.0, Effective Date: April 25, 2005, Contact-Handled Transuranic Waste Acceptance Criteria for the Waste Isolation Pilot Plant supersededs DOE/WIPP-02-3122, Revision 2.1.

DOE/WIPP-02-3122, Revision 4.0, Effective Date: December 29, 2005, ContactHandled Transuranic Waste Acceptance Criteria for the Waste Isolation Pilot Plant supersedes DOE/WIPP-02-3122, Revision 3.0. Changes to this document include the following: an update to section 3.3.6, titled Decay Heat, authorizing the use of the TRUPACT-II for the shipment of high-wattage waste with Content Code SQ 154 in response to the Nuclear Regulatory Commission's approval of Revision 21 of the TRUPACT-II Safety Analysis Report; updates to section 3.3.2 titled ${ }^{239}$ Pu Fissile Gram Equivalent and section 3.3.4 titled ${ }^{239} \mathrm{Pu}$ Equivalent Activity in response to the DOE's approval of Revision 9 of the Waste Isolation Pilot Plant Contact Handled (CH) Technical Safety Requirements (DOE/WIPP-95-2125); an update to table 3.3.2.2, titled ${ }^{239} \mathrm{Pu}$ FGE Limits for Packages, aligning the FGE limits for pipe overpack containers with table 3-1.1 of the $\mathrm{CH}$-TRAMPAC; replacement of the term "unauthorized" in table 3.3.2.2 with numerical limits; the addition of clarification text in section 3.2.5 requiring payload container identification numbers be site-specific (i.e., contain a unique site specific prefix); the deletion of text in sections 3.1.6 and 3.5.6 specific to Rocky Flats Environmental Technology Site; update to the list of acronyms and abbreviations; update of references; update of glossary, and the correction of typographical omissions. 
INDEX OF CURRENT REVISION/CHANGE NUMBER BY PAGE PAGE NUMBER REVISION NUMBER PAGE NUMBER REVISION NUMBER

vii, viii, ix, x, 1-1, 3-2, 3-3, 4.0

3-5, 3-7, 3-9, 3-10, 3-13, 4.0

3-14, 3-15, 3-16, 3-17, 4.0

3-18, 3-20, 3-21, 5-2, C-2 4.0 


\section{LIST OF ACRONYMS AND ABBREVIATIONS}

$\begin{array}{ll}\text { AK } & \text { acceptable knowledge } \\ \text { ASTM } & \text { American Society for Testing and Materials } \\ \text { ANSI } & \text { American National Standards Institute } \\ \text { CBFO } & \text { Carlsbad Field Office } \\ \text { CCA } & \text { Compliance Certification Application } \\ \text { CFR } & \text { Code of Federal Regulations } \\ \text { CH } & \text { contact-handled } \\ \text { CH-DSA } & \text { Contact-Handled Documented Safety Analysis } \\ \text { CH-TRAMPAC } & \text { Contact-Handled Transuranic Waste Authorized Methods for } \\ \text { CH-TRUCON } & \text { Payload Control } \\ \text { CH-WAC } & \text { Contact-Handled Transuranic Waste Content Codes } \\ \text { Ci } & \text { Contact-Handled Waste Acceptance Criteria } \\ \text { CPR } & \text { curie } \\ \text { DOE } & \text { U.S. Departose, plastic, and rubber } \\ \text { DOT } & \text { U.S. Department of Energy } \\ \text { DQO } & \text { data quality objective } \\ \text { EPA } & \text { U.S. Environmental Protection Agency } \\ \text { FGE } & \text { fissile gram equivalent } \\ \text { keV } & \text { kiloelectron volt } \\ \text { kg } & \text { kilogram } \\ \text { LCS } & \text { laboratory control sample } \\ \text { LLD } & \text { lower limit of detection } \\ \text { LWA } & \text { Land Withdrawal Act } \\ \text { m } & \text { cubic meter } \\ \text { MS } & \text { matrix spike } \\ \text { MSD } & \text { matrix spike duplicate } \\ \text { nCi/g } & \text { nanocuries per gram } \\ \text { NDA } & \text { nondestructive assay } \\ \text { NIST } & \text { National Institute of Standards and Technology } \\ \text { NMAC } & \text { New Mexico Administrative Code } \\ \text { NMED } & \text { U.S. Nuclear Regulatory Commission } \\ \text { NRC } & \\ & \end{array}$




\begin{tabular}{|c|c|}
\hline $\begin{array}{l}\text { PCB } \\
\text { PE-Ci }\end{array}$ & $\begin{array}{l}\text { polychlorinated biphenyl } \\
{ }^{239} \mathrm{Pu} \text { equivalent curies }\end{array}$ \\
\hline QA & quality assurance \\
\hline QAPD & Quality Assurance Program Document \\
\hline QAPjP & quality assurance project plan \\
\hline $\mathrm{QC}$ & quality control \\
\hline $\mathrm{RC}$ & radiochemistry \\
\hline RCRA & Resource Conservation and Recovery Act \\
\hline RH & remote-handled \\
\hline$\% \mathrm{R}$ & percent recovery \\
\hline RPD & relative percent difference \\
\hline RSD & relative standard deviation \\
\hline SNM & special nuclear material \\
\hline SWB & standard waste box \\
\hline TDOP & ten-drum overpack \\
\hline TMU & total measurement uncertainty \\
\hline TRU & transuranic \\
\hline TRUPACT-II & Transuranic Package Transporter-Model II \\
\hline TSDF & Treatment, Storage, and Disposal Facility \\
\hline VOC & volatile organic compound \\
\hline WAP & Waste Analysis Plan \\
\hline WCL & waste component limits \\
\hline WCP & Waste Certification Plan \\
\hline WIPP & Waste Isolation Pilot Plant \\
\hline WSPF & Waste Stream Profile Form \\
\hline WWIS & WIPP Waste Information System \\
\hline
\end{tabular}




\subsection{INTRODUCTION}

The purpose of this document is to summarize the waste acceptance criteria applicable to the transportation, storage, and disposal of contact-handled transuranic ( $\mathrm{CH}-\mathrm{TRU})$ waste at the Waste Isolation Pilot Plant (WIPP). These criteria serve as the U.S. Department of Energy's (DOE) primary directive for ensuring that $\mathrm{CH}-\mathrm{TRU}$ waste is managed and disposed of in a manner that protects human health and safety and the environment.

The authorization basis of WIPP for the disposal of CH-TRU waste includes the U.S. Department of Energy National Security and Military Applications of Nuclear Energy Authorization Act of 1980 (reference 1) and the WIPP Land Withdrawal Act (LWA; reference 2). Included in this document are the requirements and associated criteria imposed by these acts and the Resource Conservation and Recovery Act (RCRA, reference 3), as amended, on the $\mathrm{CH}-\mathrm{TRU}$ waste destined for disposal at WIPP.

The DOE TRU waste sites must certify $\mathrm{CH}-\mathrm{TRU}$ waste payload containers to the contact-handled waste acceptance criteria (CH-WAC) identified in this document. As shown in figure 1.0, the flow-down of applicable requirements to the $\mathrm{CH}$-WAC is traceable to several higher-tier documents, including the WIPP operational safety requirements derived from the WIPP CH Documented Safety Analysis (CH-DSA; reference 4), the transportation requirements for $\mathrm{CH}-\mathrm{TRU}$ wastes derived from the Transuranic Package Transporter-Model II (TRUPACT-II) and HalfPACT Certificates of Compliance (references 5 and 5a), the WIPP LWA (reference 2), the WIPP Hazardous Waste Facility Permit (reference 6), and the U.S. Environmental Protection Agency (EPA) Compliance Certification Decision and approval for PCB disposal (references 7, $34,35,36$, and 37 ). The solid arrows shown in figure 1.0 represent the flow-down of all applicable payload container-based requirements. The two dotted arrows shown in figure 1.0 represent the flow-down of summary level requirements only; i.e., the sites must reference the regulatory source documents from the U.S. Nuclear Regulatory Commission (NRC) and the New Mexico Environment Department (NMED) for a comprehensive and detailed listing of the requirements.

This $\mathrm{CH}-\mathrm{WAC}$ does not address the subject of waste characterization relating to a determination of whether the waste is hazardous; rather, the sites are referred to the Waste Analysis Plan (WAP) contained in the WIPP Hazardous Waste Facility Permit for details of the sampling and analysis protocols to be used in determining compliance with the required physical and chemical properties of the waste. Requirements and associated criteria pertaining to a determination of the radiological properties of the waste, however, are addressed in appendix A of this document. The collective information obtained from waste characterization records and acceptable knowledge (AK) serves as the basis for sites to certify that their $\mathrm{CH}$-TRU waste satisfies the WIPP waste acceptance criteria listed herein. 
Section 2.0 of this document identifies the responsible organizations and associated activities for ensuring that the $\mathrm{CH}$-TRU waste is managed in a manner that protects human health and safety and the environment. Section 3.0 identifies the authorization basis of the requirements and lists the associated waste acceptance criteria relating to the physical, chemical, and radiological attributes of the waste as well as the properties of the applicable payload containers and packages themselves.

Section 4.0 summarizes the quality assurance (QA) requirements relating to waste characterization, certification, and transportation. TRU waste sites must develop and implement a QA program that meets all applicable requirements of the Carlsbad Field Office (CBFO) Quality Assurance Program Document (QAPD; reference 8). Characterization of $\mathrm{CH}$-TRU waste must be in accordance with the performance requirements of the WIPP WAP and implemented in accordance with a site-specific quality assurance project plan (QAPjP). Certification of payload containers for shipment in the TRUPACT-II and/or HalfPACT shall be performed under a CBFO approved QA program that provides confidence for both the shipper and the receiver that the ContactHandled Transuranic Waste Authorized Methods for Payload Control (CH-TRAMPAC, reference 9) requirements have been met.

The appendices provide supplemental information relating to radioassay (appendix $A$ ) and radiotoxic inhalation hazard analyses (appendix $B$ ). A glossary is provided in appendix $C$. Appendix $D$ addresses the visual examination requirements and compliance criteria for determining if payload containers meet the criteria of section 3.2.1. Appendix $E$ describes the policy and implementation methods for the payload management of TRU alpha activity concentration when overpacking waste containers.

The $\mathrm{CH}-\mathrm{WAC}$ is a controlled document. The most current version of the $\mathrm{CH}-\mathrm{WAC}$ (including any Interim Changes) is available for downloading from the CBFO Web Page at http://www.wipp.ws/library/wac/CH-WAC.pdf. This Internet link is provided for informational purposes only and may change. 


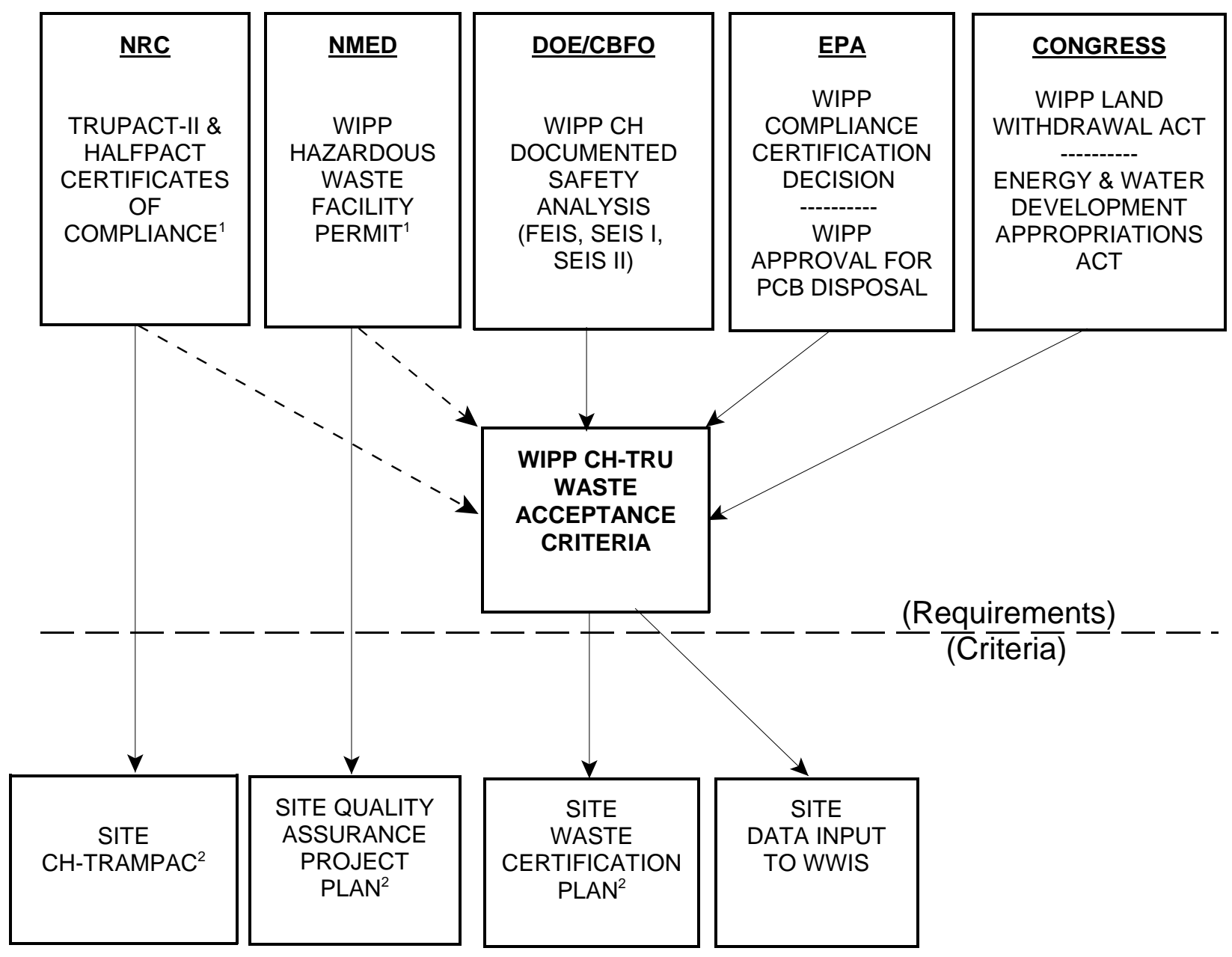

Figure 1.0 Regulatory Basis of CH-TRU Waste Acceptance Criteria

Note 1: The CH-TRAMPAC as referenced by the TRUPACT-II and HalfPACT Certificates of Compliance and the WIPP Hazardous Waste Facility Permit provide detailed requirements. This $\mathrm{CH}$-WAC only provides an overview of these requirements.

Note 2: All work performed by the site for the CBFO must be performed under an approved QA program. The sitespecific $\mathrm{CH}$-TRAMPAC can be a separate document or can be embodied in the site waste certification plan. 


\subsection{RESPONSIBILITIES}

This section identifies the responsibilities of organizations that develop and approve the WIPP CH-WAC and of those that oversee the implementation of the requirements defined herein. The responsibilities of the organizations to which these requirements apply are also identified in this section.

\subsection{DOE Headquarters}

The Assistant Secretary for Environmental Management (EM-1) provides policy and guidance for DOE environmental management sites, facilities, and operations.

\subsection{DOE Carlsbad Field Office}

The CBFO is responsible for the day-to-day management and direction of strategic planning and related activities associated with the characterization, certification, transportation, and disposal of defense TRU waste. The CBFO holds the applicable permits, certifications, and records of decision necessary for the operation and closure of the WIPP facility.

The CBFO assists the sites in resolving issues about the management of TRU waste as requested. The CBFO provides policy and oversight direction for TRU waste program activities related to site certification of waste for disposal at WIPP. The CBFO is also responsible for the following:

- $\quad$ Ensuring that the sites prepare implementation documentation and programs to meet the requirements and criteria in the $\mathrm{CH}-\mathrm{WAC}$

- $\quad$ Overseeing activities associated with the

- $\quad$ characterization and certification of $\mathrm{CH}$-TRU waste

- $\quad$ proper use of approved transportation packaging

- $\quad$ receipt, management, and disposal of $\mathrm{CH}-\mathrm{TRU}$ waste in WIPP

- $\quad$ Providing a fleet of NRC-approved Type B transportation packagings for shipment of $\mathrm{CH}$-TRU waste from the sites to WIPP

- $\quad$ Ensuring that $\mathrm{CH}-\mathrm{TRU}$ waste accepted for management and disposal at WIPP complies with the WIPP Hazardous Waste Facility Permit, applicable laws, and regulations as described in this $\mathrm{CH}-\mathrm{WAC}$

- $\quad$ Reviewing and approving proposed revisions to the $\mathrm{CH}-\mathrm{WAC}$ to ensure that environmental impacts associated with any revision are bounded by existing WIPP National Environmental Policy Act documentation including the Final 


\begin{abstract}
Environmental Impact Statement (reference 10), Final Supplemental
Environmental Impact Statement I (reference 11), and the Final Supplemental

Environmental Impact Statement II (reference 12)
\end{abstract}

- $\quad$ Reviewing and approving the sites' waste certification plan, site-specific $\mathrm{CH}$ TRAMPAC, QA plan, and QAPjP

- $\quad$ Performing site certification audits and surveillances

- Granting transportation and waste certification authority to sites

\title{
2.3 DOE Field Elements
}

Each DOE Field Element is responsible for overseeing the management of the site TRU waste program in compliance with established CBFO requirements, policies, and guidelines, and for providing liaison between the CBFO and the management and operating contractors.

\section{$2.4 \quad$ TRU Waste Sites}

Each participating site is responsible for developing and implementing site-specific TRU waste program documents (plans) that address applicable requirements and criteria pertaining to packaging, characterization, certification, and shipping of defense TRU waste to WIPP for disposal. Each participating site shall prepare a Waste Certification Plan and associated QA Plan, a site-specific CH-TRAMPAC, and a QAPjP. Methods of compliance with each requirement and associated criterion to be implemented at the site shall be described or specifically referenced and shall include procedural and administrative controls consistent with the CBFO QAPD (reference 8). TRU waste sites are required to submit these program documents to the CBFO for review and approval prior to their implementation. Sites will certify that each $\mathrm{CH}-\mathrm{TRU}$ waste payload container meets the waste acceptance criteria contained in this $\mathrm{CH}-\mathrm{WAC}$. 


\subsection{WIPP WASTE ACCEPTANCE REQUIREMENTS AND CRITERIA}

The requirements and associated criteria for acceptance of defense TRU waste at WIPP for disposal are identified in this $\mathrm{CH}$-WAC. The acceptance criteria of this $\mathrm{CH}-\mathrm{WAC}$ describe the controlling (i.e., the most restrictive) requirements to be used by the sites in preparing their waste for transportation to and disposal at the WIPP. In some instances the acceptance criteria and regulatory requirements are synonymous. The $\mathrm{CH}-\mathrm{WAC}$ requirements are derived from several source documents: the WIPP $\mathrm{CH}$-DSA (reference 4), the TRUPACT-II and/or HalfPACT Certificates of Compliance (references 5 and 5a), the WIPP LWA (reference 2), the Energy and Water Development Appropriations Act (reference 33), the WIPP Hazardous Waste Facility Permit (reference 6), the Compliance Certification Decision (reference 7), the Initial Report for PCB Disposal Authorization (reference 34), the EPA letter of approval to land dispose non-liquid PCBs at WIPP (reference 35), and the Revision to the Record of Decision for the DOE's WIPP Disposal Phase (reference 37). Definitions of terms used in this $\mathrm{CH}$-WAC are included in appendix C.

\subsection{Summary of WIPP Authorization Basis}

The purpose of section 3.0 and related appendices is to present the requirements and associated criteria that must be met for $\mathrm{CH}$-TRU waste to be transported to, managed at, and disposed of in the WIPP. The requirements and associated criteria are organized under five major headings: Container Properties, Radiological Properties, Physical Properties, Chemical Properties, and Data Package Contents. Only CH-TRU waste from a properly characterized and approved waste stream may be certified as meeting the requirements and associated criteria contained in this $\mathrm{CH}$-WAC. Any waste payload container from a waste stream that has not been preceded by an appropriate certified Waste Stream Profile Form (WSPF) is not acceptable for disposal at WIPP (reference 6, attachment B, section B-1c; reference 6, module II, section II.C.3.k).

Site-specific plans and procedures shall contain details of the processes, controls, techniques, tests, and other actions to be applied to each TRU payload container, waste stream, and shipment. Methods of compliance with each requirement shall be described and the specific procedure cited. These methods of compliance shall include procedural controls, administrative controls, and waste generation process controls. The QA requirements applicable to waste characterization, certification, and transportation are addressed in various sections of this $\mathrm{CH}-\mathrm{WAC}$ and are briefly summarized in section 4.0. The data resulting from the implementation of the plans and procedures will form the basis for verifying that $\mathrm{CH}-\mathrm{TRU}$ waste to be sent to WIPP is certified to meet the $\mathrm{CH}$ WAC by the responsible site certifying official(s).

Sites shall transmit required characterization, certification, and shipping data to WIPP using the WIPP Waste Information System (WWIS). The WWIS is an electronic database equipped with edit/limit checks to ensure that the data representing the waste 
payload containers are in compliance with this $\mathrm{CH}$-WAC. Before shipping TRU waste payload containers from a WIPP-accepted waste stream, the site shall transmit the required waste characterization, certification, and shipping data via WWIS to WIPP. Sites may periodically be requested to transmit payload container radiography reports or other data to WIPP. WIPP will not accept any waste shipments for disposal if the waste payload container information has not been correctly submitted and approved for shipment by the WWIS Data Administrator. The WWIS User's Guide-Manual (reference 13) provides the information needed by TRU waste sites to perform tasks associated with transmittal of the payload container's characterization, certification, and shipment information to WIPP.

Sites will be notified of revisions to external regulatory requirements by CBFO. Revisions of requirements in referenced documents not controlled by the DOE (but by, for example, the EPA, NRC, or NMED) shall have precedence over the values specified here if they are more restrictive. These changes will be incorporated in future revisions of the $\mathrm{CH}-\mathrm{WAC}$.

\subsubsection{DOE Operations and Safety Requirements for WIPP}

The WIPP CH-DSA (reference 4) addresses $\mathrm{CH}$-TRU waste handling and emplacement operations. The waste accepted for emplacement in the WIPP must conform to the $\mathrm{CH}$ DSA and the associated technical safety requirements (reference 14). The CH-DSA documents the safety analyses that develop and evaluate the adequacy of the WIPP safety bases necessary to ensure the safety of workers, the public, and the environment from the hazards posed by WIPP waste receiving, handling, and emplacement operations. The $\mathrm{CH}$-DSA establishes and evaluates the adequacy of the safety bases in response to plant normal and abnormal operations and postulated accident conditions.

\subsubsection{NRC Transportation Safety Requirements}

Acceptable methods for payload compliance are defined in the TRUPACT-II and HalfPACT Certificates of Compliance and implemented by the CH-TRAMPAC (reference 9). For shipments to WIPP, each site must prepare a site-specific CH-TRAMPAC describing how it will ensure compliance with each payload parameter. This technical plan shall contain sufficient detail to allow reviewers to adequately understand and evaluate the compliance methodology for each payload parameter.

Sites shall have a packaging QA program that defines the QA activities that apply to the use of NRC-approved transportation packagings equivalent to Title 10 of the Code of Federal Regulations (10 CFR) Part 71, Subpart H. (Reference 15) 


\subsubsection{NMED Hazardous Waste Facility Permit Requirements}

TRU waste is classified as TRU-mixed waste if it contains hazardous constituents regulated under the New Mexico Hazardous Waste Act. Only TRU-mixed waste and TRU waste that have been characterized in accordance with the WIPP WAP and that meet the treatment, storage, and disposal facility (TSDF) waste acceptance criteria as presented in permit conditions B-1c or II.C.3.a through II.C.3.K of the WIPP Hazardous Waste Facility Permit will be accepted at the WIPP facility for disposal in the permitted underground hazardous waste disposal unit.

Prior to disposal, each participating site shall develop and implement a QAPjP that addresses all the applicable requirements specified in the WIPP WAP. In accordance with attachment B5 of the WIPP WAP, the QAPjP will include the qualitative or quantitative criteria for making a hazardous waste determination. All site QAPjPs will be reviewed and approved by the CBFO.

\subsubsection{EPA Requirements}

\subsubsection{EPA Compliance Certification Decision}

Title 40 CFR § 194.24(c) states that the DOE shall specify the limiting values for waste components to be emplaced in the repository (reference 16). Appendix WCL (Waste Component Limits) of the Compliance Certification Application (CCA; reference 17) identifies the repository limits for several waste components including free water, metals, and cellulose, plastic, and rubber (CPR). Although the CCA does not specify limiting values for the activities and masses of specific radionuclides, table 4-6 of the CCA identifies the listed values for a number of radionuclides that are considered in the Performance Assessment. To demonstrate that the cumulative total activities of the specified radionuclides $\left({ }^{241} \mathrm{Am},{ }^{238} \mathrm{Pu},{ }^{239} \mathrm{Pu},{ }^{240} \mathrm{Pu},{ }^{242} \mathrm{Pu},{ }^{233} \mathrm{U},{ }^{234} \mathrm{U},{ }^{238} \mathrm{U},{ }^{90} \mathrm{Sr}\right.$, and ${ }^{137} \mathrm{Cs}$ ) are consistent with the levels used for the Performance Assessment and the compliance certification decision, reporting and tracking of the specified radionuclides $\left({ }^{241} \mathrm{Am},{ }^{238} \mathrm{Pu}\right.$, ${ }^{239} \mathrm{Pu},{ }^{240} \mathrm{Pu},{ }^{242} \mathrm{Pu},{ }^{233} \mathrm{U},{ }^{234} \mathrm{U},{ }^{238} \mathrm{U},{ }^{90} \mathrm{Sr}$, and ${ }^{137} \mathrm{Cs}$ ) (see appendix $\mathrm{A}$ ) is necessary as required by table $4-10$ of the CCA. TRU waste payload containers shall contain more than 100 nanocuries per gram of waste $(\mathrm{nCi} / \mathrm{g})$ of alpha-emitting TRU isotopes with halflives greater than 20 years, as specified in section 3.3.3 of this $\mathrm{CH}$-WAC.

The repository limit for free water is a maximum of 1684 cubic meters $\left(\mathrm{m}^{3}\right)$ and is met by the residual liquid criterion specified in section 3.4.1 of this $\mathrm{CH}-\mathrm{WAC}$.

The limits for metals are a minimum of $2 \times 10^{7}$ kilograms $(\mathrm{kg})$ for ferrous metals and $2 \times 10^{3} \mathrm{~kg}$ for nonferrous metals. These limits will be met in the total repository inventory by the metals that constitute the payload containers alone; thus, WIPP tracks the number and type of payload containers emplaced in the repository as reported in the WWIS by the sites (see section 3.2.1). 
The repository limit for CPR is a maximum of $2 \times 10^{7} \mathrm{~kg}$. Sites are required to estimate the CPR weights and report these estimates in the WWIS on a payload container basis as required by section 3.6.1.

Waste generators must quantify and report the activities and masses of specific radionuclides for the purpose of tracking the total radionuclide inventory of the repository as specified in section 3.3.1 of this $\mathrm{CH}$-WAC. The presence or absence of these specific radionuclides is determined from $A K$, radioassay, or both in accordance with appendix $A$ of this $\mathrm{CH}$-WAC. The results of this determination are reported in the WWIS on a payload container basis.

\subsubsection{EPA Approval for PCB Disposal}

TRU and TRU-mixed wastes containing PCBs, including PCB remediation waste, PCB bulk product waste, etc. may be disposed of at the WIPP (references $34,35,36$, and 37). Applicable waste acceptance criteria are addressed in sections 3.2 .5 (Identification/Labeling), 3.4.1 (Residual Liquids), and 3.5.6 (Polychlorinated Biphenyls) of this document.

\subsubsection{Land Withdrawal Act Requirements}

The term "WIPP" means the Waste Isolation Pilot Plant project authorized under section 213 of the Department of Energy National Security and Military Applications of Nuclear Energy Authorization Act of 1980 (Pub. L. 96-164; 93 Stat. 1259-1265) to demonstrate the safe disposal of radioactive waste materials generated by atomic energy defense activities (reference 2, section 2[19]). Hence, by law, WIPP can accept only radioactive waste generated by atomic energy defense activities of the United States (reference 2, section 2[19]).

The DOE and its predecessor agencies were engaged in a broad range of activities that fall under the heading of atomic energy defense activities. A TRU waste is eligible for disposal at WIPP if it has been generated in whole or in part by one or more of the following functions (references 18 and 19):

- $\quad$ naval reactors development

- weapons activities, including defense inertial confinement fusion

- $\quad$ verification and control technology

- $\quad$ defense nuclear materials productions

- $\quad$ defense nuclear waste and materials by-products management

- defense nuclear materials security and safeguards and security investigations

- defense research and development

Using AK, DOE sites must determine that each waste stream to be disposed of at WIPP is "defense" TRU waste. 
High-level radioactive waste or spent nuclear fuel shall neither be transported, emplaced, nor disposed of at WIPP (reference 2, section 12). Also, no transuranic waste may be transported by or for the DOE to or from WIPP, except in packages (1) the design of which has been certified by the NRC, and (2) that have been determined by the NRC to satisfy its quality assurance requirements (reference 2 , section 16(a)).

\subsubsection{Energy and Water Development Appropriations Act (Title III, General Provisions)}

The first sentenee of the-following language has appeared in various sections of Title III of the Energy and Water Development Appropriations Act for every fiscal year since 1999.

"None of the funds in this Act may be used to dispose of transuranic waste in the Waste Isolation Pilot Plant which contains concentrations of plutonium in excess of 20 percent by weight for the aggregate of any material category on the date of enactment of this Act, or is generated after such date." For the purposes of this seetion, the material eategories of transuranic waste at the Rocky Flats Environmental Technology Site include: (1) ash residues; (2) salt residues; (3) wet residues; (4) direct repackage residues; and (5) serub alloy as refereneed in the "Final Environmental Impaet Statement on Management of Certain Plutonium Residues and Serub Alloy Stored at the Roeky Flats Environmental Teehnology Site"(fReference 33):

\section{Note: The first sentenee of the language above is the only portion of the-seetion that applies to transtranie (FRU) waste generator/storage sites other than Roeky Flats.}

The CBFO strongly encourages the TRU waste generator/storage sites to work with DOE Headquarters General Counsel to obtain a determination of compliance with this language for high plutonium content material/waste that is ultimately planned for disposal at the WIPP prior to initiating TRU waste characterization activities. Evidence used to support a determination of compliance as well as the compliance decision must be included in the waste stream AK documentation. This information must also be included in the AK summary accompanying waste stream profile forms submitted to the CBFO.

\subsection{Container Properties}

\subsubsection{Description}

Acceptance Criterion. Each payload container shall be assigned to a payload shipping category. (Reference 9, section 5.1.1) Authorized payload container types include:

- 55-gallon drums 
- $\quad$ 55-gallon drums (containing a pipe component)

- $\quad$ 85-gallon drums ${ }^{1}$

- 100-gallon drums

- $\quad$ standard waste boxes (SWBs, either direct loaded, containing up to four 55-gallon drums, or containing one bin)

- $\quad$ ten drum overpacks (TDOPs, either direct loaded, containing up to ten 55-gallon drums, up to six 85-gallon drums, or one SWB)

Payload containers shall meet U.S. Department of Transportation (DOT) Specification 7A, Type A, packaging requirements (reference 14, section 5.9.12; reference 6, attachment M1, section M1-1b; reference 35, section VI.F). Payload containers must be made of steel and be in good and unimpaired condition prior to shipment from the generator/storage sites. To demonstrate compliance with the requirement that payload containers be in good and unimpaired condition, the exterior of all payload containers shall undergo $100 \%$ visual examination prior to loading into a TRUPACT-II or HalfPACT. The results of this visual examination shall be documented using the payload container integrity checklist contained in appendix D. A payload container in good and unimpaired condition 1) does not have significant rusting, 2) is of sound structural integrity, and, 3) does not leak. Significant rusting is a readily observable loss of metal due to oxidation (e.g., flaking, bubbling, or pitting) that causes degradation of the payload container's structural integrity. Rusting that causes discoloration of the payload container surface or consists of minor flaking is not considered significant. A payload container is not of sound structural integrity if it has breaches or significant denting/deformation. Breaching is defined as a penetration in the payload container that exposes the internals of the container. Significant denting/deformation is defined as damage to the payload container that results in creasing, cracking, or gouging of the metal, or damage that affects payload container closure. Dents or deformations that do not result in creasing, cracking, or gouging or affect payload container closure are not considered significant. Generator sites will report to the WWIS the number and types of payload containers planned for shipment to the WIPP (reference 17, appendix WCL).

\subsubsection{Weight Limits and Center of Gravity}

Acceptance Criterion. Each payload container, payload assembly, and loaded TRUPACT-II or HalfPACT shall comply with the weight limits shown in table 3.2.2. Weight calculations for the payload assembly must include the measurement error in

${ }^{1}$ The term "85-gallon drum" includes 75 - to 88-gallon drums. 
accordance with the CH-TRAMPAC. For TRUPACT-Il payloads, the total weight of payload container(s) in the top layer of the payload assembly shall be less than or equal to the total weight of the payload container(s) in the bottom layer of the payload assembly. In the case of drums overpacked in a TDOP, the total weight of the top layer of drums shall be less than or equal to the total weight of the bottom layer of drums. No center of gravity requirements exist for HalfPACT payloads. Calibrations of the scales used to make these weight determinations shall be in accordance with the National Institute of Standards and Technology (NIST) Handbook 44 or an equivalent standard. (Reference 9, section 2.3; Reference 21)

\section{Table 3.2.2}

\section{Weight Limits}

\begin{tabular}{|l|c|}
\hline \multicolumn{1}{|c|}{ Loaded Units } & $\begin{array}{c}\text { Maximum Gross } \\
\text { Weight (Ibs) }\end{array}$ \\
\hline \multicolumn{1}{|c|}{ Payload Containers } & $\leq 1,000$ \\
\hline 55-gallon drum & $\leq 328$ \\
\hline $\begin{array}{l}\text { 55-gallon drum containing a six-inch-diameter pipe component (i.e., a } \\
\text { standard pipe overpack) }\end{array}$ & $\leq 547$ \\
\hline $\begin{array}{l}\text { 55-gallon drum containing a twelve-inch-diameter pipe component (i.e., a } \\
\text { standard pipe overpack) }\end{array}$ & $\leq 550$ \\
\hline $\begin{array}{l}\text { 55-gallon drum containing a neutron shielded six-inch-diameter pipe } \\
\text { component (i.e., an S100 pipe overpack) }\end{array}$ & $\leq 547$ \\
\hline $\begin{array}{l}\text { 55-gallon drum containing a gamma shielded twelve-inch-diameter pipe } \\
\text { component (i.e., an S200 pipe overpack) }\end{array}$ & $\leq 547$ \\
\hline $\begin{array}{l}\text { 55-gallon drum containing a neutron shielded twelve-inch-diameter pipe } \\
\text { component (i.e., an S300 pipe overpack) }\end{array}$ & $\leq 1,000$ \\
\hline 85-gallon drum Payload Assemblies ${ }^{1}$ & $\leq 1,000$ \\
\hline 100-gallon drum & $\leq 4,000$ \\
\hline SWB & $\leq 6,700$ \\
\hline TDOP & \\
\hline \multicolumn{1}{|c|}{ Packages/Truck } & $\leq 7,600$ \\
\hline $\begin{array}{l}\text { HalfPACT payload assemblies including seven 55-gallon drums, seven pipe } \\
\text { overpacks (standard, S100, S200, or S300), four 85-gallon drums, three 100- } \\
\text { gallon drums, or one SWB }\end{array}$ & $\leq 7,265$ \\
\hline $\begin{array}{l}\text { TRUPACT-II payload assemblies including fourteen 55-gallon drums, } \\
\text { fourteen pipe overpacks (standard, S100, S200, or S300), eight 85-gallon } \\
\text { drums, six 100-gallon drums, two SWBs, or one TDOP }\end{array}$ & $\leq 80,000$ \\
\hline & \\
\hline HalfPACT & \\
\hline TRUPACT-II & \\
\hline Truck (tractor, ftrailer, and load) & \\
\hline
\end{tabular}

${ }^{1}$ Refer to section 3.2.3 of this $\mathrm{CH}-\mathrm{WAC}$ for an explanation of how payload assemblies are built. 


\subsubsection{Assembly Configurations}

Acceptance Criterion. Payload container assembly configurations authorized for shipment in the TRUPACT-II or HalfPACT shall be in accordance with tables 3.2.3.1 and 3.2.3.2, respectively (reference 9 , sections 2.1 and 2.9).

Table 3.2.3.1

TRUPACT-II Payload Assembly Configurations

\begin{tabular}{|c|l|}
\hline $\begin{array}{c}\text { Number of Payload } \\
\text { Containers in Assembly }\end{array}$ & \multicolumn{1}{|c|}{ Payload Container Configuration } \\
\hline 14 & 55-gallon drums \\
\hline 14 & 55-gallon drums configured as standard pipe overpacks \\
\hline 14 & 55-gallon drums configured as S100 pipe overpacks \\
\hline 14 & 55-gallon drums configured as S200 pipe overpacks \\
\hline 14 & 55-gallon drums configured as S300 pipe overpacks \\
\hline 8 & 85-gallon drums ${ }^{3}$ \\
\hline 6 & 100-gallon drums \\
\hline 2 & SWBs \\
\hline 1 & TDOP \\
\hline
\end{tabular}

${ }^{1}$ Payloads shall be comprised of a single payload container type. In the case of standard pipe overpacks assembled in a payload with 55-gallon drums, however, the standard pipe overpacks are considered 55gallon drums and are subject to the applicable limits.

2 Standard pipe overpacks must be assembled into seven-packs of 6-inch standard pipe overpacks only or 12-inch standard pipe overpacks only.

${ }^{3}$ A mixture of S200-A and S200-B pipe overpacks may be assembled into a single payload.

${ }^{4}$ Only the short 85-gallon drum is authorized for transport within the TRUPACT-II as a payload container.

Table 3.2.3.2

HalfPACT Payload Assembly Configurations

\begin{tabular}{|c|l|}
\hline $\begin{array}{c}\text { Number of Payload } \\
\text { Containers in Assembly }\end{array}$ & \multicolumn{1}{|c|}{ Payload Container Configuration } \\
\hline 7 & 55-gallon drums \\
\hline 7 & 55-gallon drums configured as standard pipe overpacks \\
\hline 7 & 55-gallon drums configured as S100 pipe overpacks \\
\hline 7 & 55-gallon drums configured as S200 pipe overpacks \\
\hline 7 & 55-gallon drums configured as S300 pipe overpacks \\
\hline 4 & 85-gallon drums ${ }^{3}$ \\
\hline 3 & 100-gallon drums \\
\hline 1 & SWB \\
\hline
\end{tabular}


${ }^{1}$ Payloads shall be comprised of a single payload container type. In the case of standard pipe overpacks assembled in a payload with 55-gallon drums, the standard pipe overpacks are considered 55-gallon drums and are subject to applicable limits.

${ }^{2}$ Standard pipe overpacks must be assembled into seven-packs of 6 -inch standard pipe overpacks only or 12-inch standard pipe overpacks only.

${ }^{3}$ A mixture of S200-A and S200-B pipe overpacks may be assembled into a single payload.

${ }^{4}$ The short and tall 85-gallon drums are authorized for transport within the HalfPACT.

TRUPACT-II and HalfPACT payloads may contain assemblies of payload containers belonging to the same shipping category or different shipping categories (reference 9 , section 6).

\subsubsection{Removable Surface Contamination}

Acceptance Criterion. Removable surface contamination on $\mathrm{CH}-\mathrm{TRU}$ waste payload containers, payload assemblies, and packagings shall not exceed $20 \mathrm{dpm} / 100 \mathrm{~cm}^{2}$ alpha and $200 \mathrm{dpm} / 100 \mathrm{~cm}^{2}$ beta-gamma (reference 14, section 5.9.12; reference 6 , attachment M1, section M1-1d[2]; reference 22; and reference 23). The fixing of surface contamination to meet these criteria is not allowed by WIPP in accordance with best management practices for ensuring worker radiation dose as low as reasonable achievable.

\subsubsection{Identification/Labeling}

Acceptance Criterion. Each payload container to be shipped in a TRUPACT-II or a HalfPACT shall be labeled with a unique payload container identification number using bar code labels permanently attached in conspicuous locations (reference 9 , section 2.4). The unique payload container identification number shall include a site identifier as a prefix (reference 9, section 6.2.1).

The payload container identification number shall be in medium to low density Code 39 bar code symbology as required by American National Standards Institute (ANSI) standard ANSI/AIM BC1-1995 (reference 24) in characters at least one inch high and alphanumeric characters at least one-half inch high. In the case of 55-, 85-, and 100gallon drums, a minimum of three bar code identification labels shall be placed at approximately equal intervals around the circumference of the drum (120 degrees for 3 labels, 90 degrees for 4 labels, etc.) so that at least one label is clearly visible when the drums are assembled into a payload (i.e., a label must be visible after slip sheets and wrapping are applied). In the case of SWBs, bar code labels are required on the flat sides of the SWBs. (Reference 25) For TDOPs, a minimum of one bar code is required.

Payload containers shall be marked "Caution Radioactive Material" using a yellow and magenta label as specified in 10 CFR Part 835 (reference 23). Those payload containers whose contents are also RCRA regulated (mixed-TRU) shall be additionally marked "Hazardous Waste" as specified in 40 CFR § 262.32 (reference 26). For TRU 
and TRU-mixed wastes containing PCBs, the payload containers shall be marked in accordance with 40 CFR $\$ 761.40$ (reference 36). Additionally, DOT Type B packages (i.e., the TRUPACT-II and HalfPACT) containing PCBs must be properly marked in accordance with 40 CFR $\S 761.40$ (references 35 and 36).

If an empty 55-, 85-, or 100-gallon drum is used as dunnage to complete a payload configuration, the dunnage container shall be labeled with the following information:

- Unique payload container identification number

- "EMPTY" or "DUNNAGE"

If a seven-pack of only dunnage 55-gallon drums, a four-pack of only dunnage 85-gallon drums, a three-pack of only dunnage 100-gallon drums, or a dunnage SWB is used in the TRUPACT-II, the container(s) shall be labeled only "EMPTY" or "DUNNAGE," and the unique container identification number label is not required for these containers (reference 9, section 2.4.1).

\subsubsection{Dunnage}

Acceptance Criterion. A shipper shall use empty 55-gallon drums, 85-gallon drums, 100gallon drums, or a SWB as dunnage to complete a payload configuration if too few loaded payload containers are available that meet transportation requirements. The dunnage container(s) must meet the specifications of section 2.9 of the $\mathrm{CH}$-TRAMPAC, with the exception that dunnage containers shall have at least one open vent port (i.e., not filtered or plugged). Note that empty 55-gallon drum(s) can be used as dunnage container(s) to complete a payload of pipe overpacks. (Reference 9, section 2.2.1)

To maximize the efficiency of disposal operations at the WIPP, the use of dunnage drums should be minimized. In the event the use of dunnage drums cannot be avoided, the preferred practice for maximizing the efficiency of waste handling and the utilization of disposal room capacity is to ship them in assemblies (e. g., a seven-pack assembly of 55-gallon drums). The use of dunnage drums is reviewed and approved concurrently with the review and approval of shipment assemblies by the WWIS Data Administrator on a case-by-case basis.

\subsubsection{Filter Vents}

Acceptance Criterion. Payload containers that have been stored in an unvented condition (i.e., no filter and/or unpunctured liner) shall be aspirated for a specific length of time as described in the $\mathrm{CH}$-TRAMPAC to ensure equilibration of any gases that may have accumulated in the closed payload container. (Reference 9, section 5.3.1)

Each payload container shall have one or more filter vents (reference 14, section 5.9.12; reference 9, section 2.5.1; reference 6, attachment M1-1b). These filter vents shall meet the specifications of the WIPP Hazardous Waste Facility Permit and CH-TRAMPAC, as 
applicable (reference 6, attachment B1; reference 9, section 2.5.1). The model number of each filter vent or combination of filter vents installed on a payload container shall be reported to the WWIS. A listing of available CBFO filter vent models is provided on the CBFO Web Page (http://www.wipp.ws/transport.htm). This Internet link is provided for informational purposes only and may change.

\subsection{Radiological Properties}

With respect to the required radiological properties identified within this section, they can be divided into two distinct groups.

The first group includes the activities and masses of the ten WIPP-tracked radionuclides (i.e., ${ }^{241} \mathrm{Am},{ }^{238} \mathrm{Pu},{ }^{239} \mathrm{Pu},{ }^{240} \mathrm{Pu},{ }^{242} \mathrm{Pu},{ }^{233} \mathrm{U},{ }^{234} \mathrm{U},{ }^{238} \mathrm{U},{ }^{90} \mathrm{Sr}$, and ${ }^{137} \mathrm{Cs}$ ) and the TRU alpha activity concentration (i.e., $>100 \mathrm{nCi} / \mathrm{g}$ of alpha-emitting TRU isotopes with half lives greater than 20 years) of the waste. This set of radiological properties is regulated by the EPA in accordance with 40 CFR Parts 191 and 194 (references 27 and 16). Estimates of their activities and masses shall be derived from a system of controls certified by CBFO that includes AK, computations, measurements, sampling, etc. (reference 17, appendix WCL). Appendix A provides the methods and requirements by which to characterize the radiological composition of the $\mathrm{CH}$-TRU waste utilizing radioassay techniques.

The second group includes the remaining radionuclides contributing to the ${ }^{239} \mathrm{Pu}$ fissile gram equivalent (FGE), the ${ }^{239} \mathrm{Pu}$ equivalent curies (PE-Ci), and the decay heat of the payload container. This set of radiological data is regulated both by the NRC as specified in the $\mathrm{CH}$-TRAMPAC (reference 9) and the CBFO as required by the WIPP Technical Safety Requirements (reference 14). PE-Ci quantities shall be calculated for each payload container in accordance with appendix B. Any CH-TRAMPAC compliant method may be used to quantify the remaining radiological properties at the discretion of the shipping facility. Appendix A provides recommended radioassay methods by which to characterize the remaining radiological properties. However, the resulting data (e.g., AK from Safeguards and Security data), the source/method from which the data was generated, and the basis for the reliability of the data shall be submitted to and approved by CBFO prior to use.

\subsubsection{Radionuclide Composition}

Acceptance Criterion. The activities and masses of ${ }^{241} \mathrm{Am},{ }^{238} \mathrm{Pu},{ }^{239} \mathrm{Pu},{ }^{240} \mathrm{Pu},{ }^{242} \mathrm{Pu},{ }^{233} \mathrm{U}$, ${ }^{234} \mathrm{U},{ }^{238} \mathrm{U},{ }^{90} \mathrm{Sr}$, and ${ }^{137} \mathrm{Cs}$ shall be established on a payload container basis for purposes of tracking their contributions to the total WIPP radionuclide inventory (reference 17, appendix WCL). The estimated activities and masses, including their associated total measurement uncertainties (TMU) expressed in terms of one standard deviation, for these ten radionuclides shall be reported to the WWIS on a payload container basis. For any of these ten radionuclides whose presence can be substantiated from AK, direct 
measurement, computations, or a combination thereof, and whose measured data are determined to be below the lower limit of detection (LLD) for that radionuclide, the site shall report the character string "< LLD" to the WWIS for the activity and mass of that radionuclide; otherwise a value of zero shall be reported. Quantitative estimates for LLD shall not be used when calculating related radiological properties of the waste such as TRU alpha activity concentration, ${ }^{239} \mathrm{Pu}$ fissile gram equivalent, decay heat, etc. See appendix A, section A.3, for information pertaining to the development and application of LLD.

In addition, all radionuclides other than the ten WIPP-tracked radionuclides (i.e., ${ }^{241} \mathrm{Am}$, ${ }^{238} \mathrm{Pu},{ }^{239} \mathrm{Pu},{ }^{240} \mathrm{Pu},{ }^{242} \mathrm{Pu},{ }^{233} \mathrm{U},{ }^{234} \mathrm{U},{ }^{238} \mathrm{U},{ }^{90} \mathrm{Sr}$, and ${ }^{137} \mathrm{Cs}$ ) that contribute to $95 \%$ of the radioactive hazard for the payload container shall be reported on the TRUPACT-II or HalfPACT bill of lading or manifest in accordance with 49 CFR $\$ 172.203$ and 49 CFR $\S 173.433$ (reference 28, reference 29). The activities and masses of these other radioisotopes shall also be reported to the WWIS along with their associated TMU, expressed in terms of one standard deviation for each waste container (reference 17).

\subsection{2 ${ }^{239} \mathrm{Pu}$ Fissile Gram Equivalent}

Acceptance Criterion. For each payload container and loaded TRUPACT-II or HalfPACT, the sum of ${ }^{239} \mathrm{Pu}$ FGE plus two times its associated TMU, expressed in terms of one standard deviation, shall comply with the limits in either table 3.3.2.1 or table 3.3.2.2, as applicable (reference 14, section 5.9.11; reference 9, section 3.1.1). The values calculated for ${ }^{239} \mathrm{Pu}$ FGE and its associated TMU (expressed in terms of one standard deviation) shall be reported to the WWIS for each payload container.

Table 3.3.2.1

${ }^{239} \mathrm{Pu}$ FGE Limits for Payload Containers

\begin{tabular}{|c|c|c|}
\hline Payload Containers & $\begin{array}{c}\text { Beryllium Mass } \\
\text { Limit }^{1}\end{array}$ & $\begin{array}{c}{ }^{239} \text { Pu FGE } \\
\text { Limit }^{2}\end{array}$ \\
\hline \multicolumn{2}{|c|}{ Non-Machine-Compacted Waste } \\
\hline 55- (excluding pipe overpacks), 85-, and 100-gallon drums & $\begin{array}{c}\leq 1 \% \text { by weight of the } \\
\text { waste }\end{array}$ & $\leq 200$ \\
\hline $\begin{array}{c}\text { 55-gallon drum configured as a pipe overpack } \\
\text { (i.e., a standard, S100, S200, or S300 pipe overpack) }\end{array}$ & $\leq 5 \mathrm{~kg}$ & $\leq 200$ \\
\hline SWB & $\begin{array}{c}\leq 1 \% \text { by weight of the } \\
\text { waste up to } 18.14 \mathrm{~kg} \text { and } \\
\text { is particulate }\end{array}$ & $\leq 325$ \\
\hline TDOP & $\begin{array}{r}\leq 1 \% \text { by weight of the } \\
\text { waste up to } 18.14 \mathrm{~kg} \text { and } \\
\text { is particulate }\end{array}$ & $\leq 325$ \\
\hline
\end{tabular}




\begin{tabular}{|c|c|c|}
\hline Payload Containers & $\begin{array}{l}\text { Beryllium Mass } \\
\text { Limit }^{1}\end{array}$ & $\begin{array}{c}{ }^{239} \mathrm{Pu} \text { FGE } \\
\text { Limit }^{2}\end{array}$ \\
\hline 55- (excluding pipe overpacks), 85-, and 100-gallon drums & $\begin{array}{l}>1 \% \text { by weight of the } \\
\text { waste up to } 100 \mathrm{~kg}\end{array}$ & $\leq 100$ \\
\hline SWB & $\begin{array}{c}>1 \% \text { by weight of the } \\
\text { waste up to } 18.14 \mathrm{~kg} \text { and } \\
\text { is particulate }\end{array}$ & $\leq 100$ \\
\hline TDOP & $\begin{array}{c}>1 \% \text { by weight of the } \\
\text { waste up to } 18.14 \mathrm{~kg} \text { and } \\
\text { is particulate }\end{array}$ & $\leq 100$ \\
\hline \multicolumn{3}{|c|}{ Machine-Compacted Waste } \\
\hline 55-(excluding pipe overpacks), 85-, and 100-gallon drums & $\begin{array}{c}\leq 1 \% \text { by weight of the } \\
\text { waste }\end{array}$ & $\leq 200^{4}$ \\
\hline SWB $^{5}$ & $\begin{array}{c}\leq 1 \% \text { by weight of the } \\
\text { waste up to } 18.14 \mathrm{~kg} \text { and } \\
\text { is particulate }\end{array}$ & $\begin{array}{l}\leq 250 \\
\leq 185\end{array}$ \\
\hline TDOP $^{5}$ & $\begin{array}{c}\leq 1 \% \text { by weight of the } \\
\text { waste up to } 18.14 \mathrm{~kg} \text { and } \\
\text { is particulate }\end{array}$ & $\begin{array}{l}\leq 250 \\
\leq 185\end{array}$ \\
\hline
\end{tabular}

${ }^{1}$ Beryllium includes both the metal (Be) and its oxide (BeO).

${ }^{2}$ The FGE limit given applies to the payload container regardless of ${ }^{240} \mathrm{Pu}$ content in the package.

${ }^{3}$ Particulate beryllium includes fines or shavings.

${ }^{4}$ The ${ }^{239} \mathrm{Pu}$ FGE limit of 200 applies to waste that has been compacted such that the distribution and form of polyethylene in the waste does not exceed $0.646 \mathrm{~g} / \mathrm{cm}^{3}$, i.e., $70 \%$ of the theoretical full density of polyethylene $\left(0.923 \mathrm{~g} / \mathrm{cm}^{3}\right)$. If $70 \%$ of the theoretical full density of polyethylene is exceeded, then the ${ }^{239} \mathrm{Pu}$ FGE limit shall not exceed 170 FGE unless the dimensions of the payload containers (e.g., 100-gallon drums) ensure a minimum 0.5 " separation between their compacted waste contents and other axially adjacent payload containers (reference 14, section 5.9.11).

${ }^{5}$ Waste that has been compacted such that the distribution and form of polyethylene in the waste exceeds $0.184 \mathrm{~g} / \mathrm{cm}^{3}$, i.e., $20 \%$ of the theoretical full density of polyethylene $\left(0.923 \mathrm{~g} / \mathrm{cm}^{3}\right)$, is not allowed in a direct toaded SWB OF TDOP.

Table 3.3.2.2

\section{${ }^{239}$ Pu FGE Limits for Packages}

\begin{tabular}{|c|c|c|c|}
\hline Payload Packages & $\begin{array}{l}{ }^{239} \text { Pu FGE Limit } \\
\text { (No Credit for }{ }^{240} \text { Pu Poisoning) }\end{array}$ & \multicolumn{2}{|c|}{$\begin{array}{c}{ }^{239} \mathrm{Pu} \text { FGE Limit } \\
\left.\text { (Credit for }{ }^{240} \mathrm{Pu} \text { Poisoning }{ }^{1}\right)\end{array}$} \\
\hline \multicolumn{4}{|c|}{ Applicable to Beryllium ${ }^{2}$ Mass $\leq 1 \%$ by Weight of the Waste and Non-Machine-Compacted Waste } \\
\hline \multirow{3}{*}{$\begin{array}{c}\text { TRUPACT-II } \\
\text { (containing either } 14 \text { 55-gallon drums, } \\
8 \text { 85-gallon drums, } 6 \text { 100-gallon } \\
\text { drums, } 2 \text { SWBs, or } 1 \text { TDOP }^{3} \text { ) }\end{array}$} & \multirow{3}{*}{$\leq 325$} & $5 \mathrm{~g}^{240} \mathrm{Pu}$ & $\leq 340$ \\
\hline & & $15 \mathrm{~g}^{240} \mathrm{Pu}$ & $\leq 360$ \\
\hline & & $25 \mathrm{~g}^{240} \mathrm{Pu}$ & $\leq 380$ \\
\hline
\end{tabular}




\begin{tabular}{|c|c|c|c|}
\hline Payload Packages & $\begin{array}{l}{ }^{239} \mathrm{Pu} \text { FGE Limit } \\
\text { (No Credit for }{ }^{240} \text { Pu Poisoning) }\end{array}$ & \multicolumn{2}{|c|}{$\begin{array}{c}{ }^{239} \mathrm{Pu} \text { FGE Limit } \\
\text { (Credit for }^{240} \mathrm{Pu} \text { Poisoning }{ }^{1} \text { ) }\end{array}$} \\
\hline $\begin{array}{c}\text { TRUPACT-II } \\
\text { (containing either } 14 \text { standard pipe } \\
\text { overpacks, } 14 \text { S100 pipe overpacks, } \\
14 \text { S200 pipe overpacks, or } 14 \text { S300 } \\
\text { pipe overpacks) }\end{array}$ & $\leq 2,800$ & \multicolumn{2}{|c|}{$\begin{array}{l}\text { Unauthorized } \\
\quad \leq 2,800\end{array}$} \\
\hline \multirow{3}{*}{$\begin{array}{c}\text { HalfPACT } \\
\text { (containing either } 7 \text { 55-gallon drums, } \\
4 \text { 85-gallon drums, } 3 \text { 100-gallon } \\
\text { drums, or } 1 \text { SWB) }\end{array}$} & \multirow{3}{*}{$\leq 325$} & $5 \mathrm{~g}^{240} \mathrm{Pu}$ & $\leq 340$ \\
\hline & & $15 \mathrm{~g}^{240} \mathrm{Pu}$ & $\leq 360$ \\
\hline & & $25 \mathrm{~g}^{240} \mathrm{Pu}$ & $\leq 380$ \\
\hline $\begin{array}{c}\text { HalfPACT } \\
\text { (containing either } 7 \text { standard pipe } \\
\text { overpacks, } 7 \text { S100 pipe overpacks, } 7 \\
\text { S200 pipe overpacks, or } 7 \text { S300 pipe } \\
\text { overpacks) }\end{array}$ & $\leq 1,400$ & \multicolumn{2}{|c|}{$\begin{array}{l}\text { Unauthorized } \\
\leq 1,400\end{array}$} \\
\hline \multicolumn{4}{|c|}{ Applicable to Beryllium ${ }^{2}$ Mass $>1 \%$ by Weight of the Waste and Non-Machine-Compacted Waste } \\
\hline $\begin{array}{c}\text { TRUPACT-II } \\
\text { (containing either } 1455 \text {-gallon drums, } \\
8 \text { 85-gallon drums, } 6 \text { 100-gallon } \\
\text { drums, } 2 \text { SWBs, or } 1 \text { TDOP) }\end{array}$ & $\leq 100$ & \multicolumn{2}{|c|}{$\begin{array}{l}\text { Unauthorized } \\
\quad \leq 100\end{array}$} \\
\hline $\begin{array}{c}\text { TRUPACT-II } \\
\text { (containing either } 14 \text { standard pipe } \\
\text { overpacks, } 14 \text { S100 pipe overpacks, } \\
14 \text { S200 pipe overpacks, or } 14 \text { S300 } \\
\text { pipe overpacks) }\end{array}$ & $\leq 2,800$ & \multicolumn{2}{|c|}{$\leq 2,800$} \\
\hline $\begin{array}{c}\text { HalfPACT } \\
\text { (containing either } 7 \text { 55-gallon drums, } \\
4 \text { 85-gallon drums, } 3 \text { 100-gallon } \\
\text { drums, or } 1 \text { SWB) }\end{array}$ & $\leq 100$ & \multicolumn{2}{|c|}{$\begin{array}{l}\text { Unauthorized } \\
\quad \leq 100\end{array}$} \\
\hline $\begin{array}{c}\text { HalfPACT } \\
\text { (containing either } 7 \text { standard pipe } \\
\text { overpacks, } 7 \text { S100 pipe overpacks, } 7 \\
\text { S200 pipe overpacks, or } 7 \text { S300 pipe } \\
\text { overpacks) }\end{array}$ & $\leq 1,400$ & \multicolumn{2}{|c|}{$\leq 1,400$} \\
\hline \multicolumn{4}{|c|}{ Applicable to Beryllium ${ }^{2}$ Mass $\leq 1 \%$ by Weight of the Waste and Machine-Compacted Waste ${ }^{4}$} \\
\hline $\begin{array}{c}\text { TRUPACT-II } \\
\text { (containing either } 1455 \text {-gallon drums, } \\
8 \text { 85-gallon drums, } 6 \text { 100-gallon } \\
\text { drums, } 2 \text { SWBs, or } 1 \text { TDOP) }\end{array}$ & $\leq 250$ & $\forall n$ & ized \\
\hline
\end{tabular}




\begin{tabular}{|c|c|c|}
\hline Payload Packages & $\begin{array}{l}{ }^{239} \mathrm{Pu} \text { FGE Limit } \\
\text { (No Credit for }{ }^{240} \text { Pu Poisoning) }\end{array}$ & $\begin{array}{c}{ }^{239} \mathrm{Pu} \text { FGE Limit } \\
\text { (Credit for }^{240} \mathrm{Pu} \text { Poisoning }{ }^{1} \text { ) }\end{array}$ \\
\hline $\begin{array}{c}\text { HalfPACT } \\
\text { (containing either } 755 \text {-gallon drums, } \\
4 \text { 85-gallon drums, } 3 \text { 100-gallon } \\
\text { drums, or } 1 \text { SWB) }\end{array}$ & $\leq 250$ & $\begin{array}{l}\text { Unauthorized } \\
\quad \leq 250\end{array}$ \\
\hline $\begin{array}{c}\text { TRUPACT-II } \\
\text { (containing either 14 55-gallon drums, } \\
8 \text { 85-gallon drums, or } 6 \text { 100-gallon } \\
\text { drums) }\end{array}$ & $\begin{array}{c}\quad \leq 325 \\
\text { (with controls }^{4} \text { ) }\end{array}$ & $\begin{array}{l}\text { Unauthorized } \\
\quad \leq 325 \\
\text { (with controls }{ }^{4} \text { ) }\end{array}$ \\
\hline $\begin{array}{c}\text { HalfPACT } \\
\text { (containing either } 7 \text { 55-gallon drums, } \\
4 \text { 85-gallon drums, or } 3 \text { 100-gallon } \\
\text { drums) }\end{array}$ & $\begin{array}{c}\leq 325 \\
\text { (with controls }{ }^{4} \text { ) }\end{array}$ & $\begin{array}{l}\text { Unauthorized } \\
\quad \leq 325 \\
\text { (with controls }{ }^{4} \text { ) }\end{array}$ \\
\hline \multicolumn{3}{|c|}{ Applicable to Beryllium ${ }^{2}$ Mass $>1 \%$ by Weight of the Waste and Machine-Compacted Waste ${ }^{4}$} \\
\hline
\end{tabular}

${ }^{1}$ The numbers $0,5,15$, and 25 represent the minimum ${ }^{240} \mathrm{Pu}$ content of the payload expressed in grams that must be exceeded to take credit for the higher FGE loading limit. The minimum ${ }^{240} \mathrm{Pu}$ content for the payload shall be determined after subtraction of two times the error.

${ }^{2}$ Beryllium includes both the metal $(\mathrm{Be})$ and its oxide $(\mathrm{BeO})$.

${ }^{3}$ The TDOP cannot take credit for ${ }^{240} \mathrm{Pu}$ poisoning.

${ }^{4}$ See section 3.1.1 of the CH-TRAMPAC (reference 9).

\subsubsection{TRU Alpha Activity Concentration}

Acceptance Criterion. TRU waste payload containers shall contain more than $100 \mathrm{nCi} / \mathrm{g}$ of alpha-emitting TRU isotopes with half-lives greater than 20 years. Without taking into consideration the TMU, the TRU alpha activity concentration for a payload container is determined by dividing the TRU alpha activity of the waste by the weight of the waste. The weight of the waste is the weight of the material placed into the payload container (i.e., the net weight of the container). The weight of the waste is typically determined by subtracting the tare weight of the payload container (including the weight of the rigid liner and any shielding external from the waste, if applicable) from the gross weight of the payload container. In the event waste containers (e.g., 55-gallon drums) that have been radioassayed are overpacked in a payload container (e.g., in an SWB), sites shall sum the individual TRU alpha activity values of the individual waste containers and divide by the sum of the individual net waste weights (i.e., less container, shielding, and liner weights as appropriate) to determine the activity per gram for the payload container. Waste containers selected for payload management shall comply with the policy for the management of TRU alpha activity concentration (see appendix E). Loading a 55-gallon pipe-overpack with cans is considered direct loading - not overpacking for the purposes of calculating the weight of the container. The TRU alpha activity concentration shall be 
reported to the WWIS; however, there are no reporting requirements for its associated TMU. (Reference 2, section 2[18]; Reference 17, chapter 4)

\subsection{4 ${ }^{239} \mathrm{Pu}$ Equivalent Activity}

Acceptance Criterion. ${ }^{239} \mathrm{Pu}$ equivalent curie (PE-Ci) limits are shown in table 3.3.4. PE-Ci quantities shall be calculated for each payload container (see appendix B) and reported to WIPP using the WWIS. There are no reporting requirements for the associated TMU. (Reference 14, section 5.9.12)

Table 3.3.4

PE-Ci Limits

\begin{tabular}{|c|c|c|}
\hline Waste Container & Packing Configuration & PE-Ci Limit \\
\hline \multirow{4}{*}{$\begin{array}{l}\text { 55-gallondrumingood } \\
\text { eondition }\end{array}$} & Direet load - allapproved waste forms & $\leq 80$ \\
\hline & Difeetload-solidified/vitriffied waste-only & $\leq 1,800$ \\
\hline & $\begin{array}{l}\text { Overpacked into a 85-gallon dfum, SWB, of } \\
\text { FDOP_-allapproved waste forms }\end{array}$ & $\longleftarrow 1,100$ \\
\hline & $\begin{array}{l}\text { Overpacked into a 85-gallon dfum, SWB, of } \\
\text { 干DOP_-solidified/vitrified waste-only }\end{array}$ & 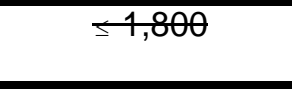 \\
\hline \multirow[t]{2}{*}{$\begin{array}{l}\text { 55-gallen drumin damaged } \\
\text { eondition }\end{array}$} & $\begin{array}{l}\text { Overpackedinto a 85-gallon dfum, SWB, of } \\
\text { FDOP-all approved waste forms }\end{array}$ & $\begin{array}{l}\leq 80, \leq 130, \leq 130 \\
\text { fespeetively }\end{array}$ \\
\hline & $\begin{array}{l}\text { Overpacked into a 85-gallon dfum, SWB, of } \\
\text { FDOP_-solidified/vitriffied waste- onlly }\end{array}$ & 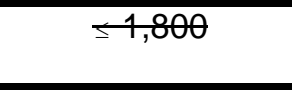 \\
\hline $\begin{array}{l}\text { 55-gallon pipe overpack in } \\
\text { good condition }\end{array}$ & Bireet load - allapproved waste forms & 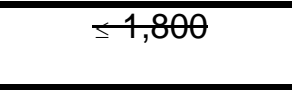 \\
\hline \multirow{4}{*}{$\begin{array}{l}\text { 85-gallondfumingood } \\
\text { eondition }\end{array}$} & Difeet load - all approved waste forms & $\leq 80$ \\
\hline & Bifeet load-solidified/vitriffied waste only & $\leq 1,800$ \\
\hline & $\begin{array}{l}\text { Overpackedinto a TDOP_-all approved } \\
\text { waste forms }\end{array}$ & 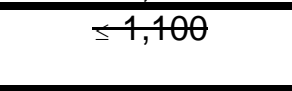 \\
\hline & $\begin{array}{l}\text { Overpackedinto a TDOP_-solidified/vittified } \\
\text { waste-only }\end{array}$ & 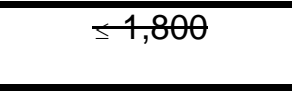 \\
\hline \multirow[t]{2}{*}{$\begin{array}{l}\text { 85-gallen drumindamaged } \\
\text { eondition }\end{array}$} & $\begin{array}{l}\text { Overpacked into a TDOP - allapproved } \\
\text { waste forms }\end{array}$ & $\leftrightarrows 130$ \\
\hline & $\begin{array}{l}\text { Overpacked into a ТФОР-solidified/vittrified } \\
\text { waste only }\end{array}$ & $\leftrightarrows 1,800$ \\
\hline \multirow{2}{*}{$\begin{array}{l}\text { 100-gallon drum in good } \\
\text { eondition }\end{array}$} & Direet load - all approved waste forms & 580 \\
\hline & Bifeetload-solidified/vitriffied waste only & 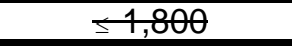 \\
\hline \multirow[t]{4}{*}{ SWB in good condition } & $\begin{array}{l}\text { Oireet load (or a bin) - all approved waste } \\
\text { forms }\end{array}$ & $\longleftarrow 130$ \\
\hline & $\begin{array}{l}\text { Direet load (or a bin) - solidified/vitrified } \\
\text { waste only }\end{array}$ & 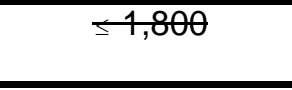 \\
\hline & $\begin{array}{l}\text { Overpacked into a TDOP-allapproved } \\
\text { waste forms }\end{array}$ & 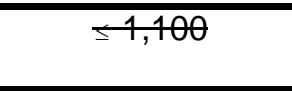 \\
\hline & $\begin{array}{l}\text { Overpacked into a TDOP - solidified/vitrified } \\
\text { waste only }\end{array}$ & 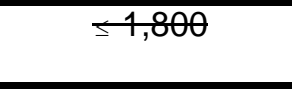 \\
\hline SWB in damaged condition & $\begin{array}{l}\text { Overpacked into a TDOP - all approved } \\
\text { waste forms }\end{array}$ & $\longleftarrow 130$ \\
\hline
\end{tabular}




\begin{tabular}{|c|c|c|}
\hline Waste-Container & Packing Configuration & PE-Citimit \\
\hline & $\begin{array}{l}\text { Overpackedinto a fDOP-solielified/vittrified } \\
\text { waste only }\end{array}$ & $\leftrightarrows 1,800$ \\
\hline \multirow[t]{2}{*}{ FDOP ingoodeondition } & Eireet load - all approved waste forms & $\leftrightarrows 130$ \\
\hline & Bireet load-solidified/vittrified waste- only & $\leftrightarrows 1,800$ \\
\hline
\end{tabular}

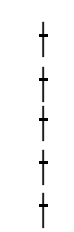

\begin{tabular}{|c|c|c|}
\hline Payload Container & Packing Configuration & PE-Ci Limit \\
\hline 55-, 85-, and 100-gallon drum & $\begin{array}{l}\text { Direct loaded - all approved waste forms } \\
\text { other than solidified/vitrified waste }\end{array}$ & $\leq 80 \mathrm{PE}-\mathrm{Ci}$ \\
\hline SWB & $\begin{array}{l}\text { Direct loaded (or a bin) - all approved waste } \\
\text { forms other than solidified/vitrified waste }\end{array}$ & $\leq 560 \mathrm{PE}-\mathrm{Ci}$ \\
\hline TDOP & $\begin{array}{l}\text { Direct loaded - all approved waste forms } \\
\text { other than solidified/vitrified waste }\end{array}$ & $\leq 560 \mathrm{PE}-\mathrm{Ci}$ \\
\hline 85-gallon drum & $\begin{array}{l}\text { Overpacking an undamaged }{ }^{1} 55 \text {-gallon drum } \\
\text { - all approved waste forms other than } \\
\text { solidified/vitrified waste }\end{array}$ & $\leq 1100 \mathrm{PE}-\mathrm{Ci}$ \\
\hline SWB, TDOP & $\begin{array}{l}\text { Overpacking an assembly of undamaged } \\
55-\text { or } 85 \text {-gallon drums with no single } \\
\text { payload container within the assembly } \\
\text { exceeding } 1100 \mathrm{PE}-\mathrm{Ci} \text { - all approved waste } \\
\text { forms other than solidified/vitrified waste }\end{array}$ & $\leq 1200$ PE-Ci \\
\hline TDOP & $\begin{array}{l}\text { Overpacking an undamaged }{ }^{1} \text { SWB - all } \\
\text { approved waste forms other than } \\
\text { solidified/vitrified waste }\end{array}$ & $\leq 1200 \mathrm{PE}-\mathrm{Ci}$ \\
\hline $\begin{array}{l}\text { Pipe Overpacks (Standard, } \\
\text { S100, S200, and S300) }\end{array}$ & All approved waste forms & $\leq 1800 \mathrm{PE}-\mathrm{Ci}$ \\
\hline All & Solidified/vitrified waste & $\leq 1800 \mathrm{PE}-\mathrm{Ci}$ \\
\hline
\end{tabular}

${ }^{1}$ An undamaged container provides an additional barrier should a breach occur in the overpack. When overpacking one or more damaged waste containers, direct loaded PE-Ci limits apply.

\subsubsection{Radiation Dose Equivalent Rate}

Acceptance Criterion. The external radiation dose equivalent rate of individual payload containers shall be $\leq 200 \mathrm{mrem} / \mathrm{h}$ at the surface with the exception of the S100 and S300 pipe overpacks which are limited to $\leq 179 \mathrm{mrem} / \mathrm{h}$ and $\leq 155 \mathrm{mrem} / \mathrm{h}$, respectively, at the surface (reference 9, section 3.2; reference 14, section 5.9.12). The external radiation dose equivalent rate of the TRUPACT-II and HalfPACT shall be $\leq 200 \mathrm{mrem} / \mathrm{h}$ at the surface and $\leq 10 \mathrm{mrem} / \mathrm{h}$ at $2 \mathrm{~m}$ (reference 9, section 3.2). Internal payload container shielding shall not be used to meet this criterion, except for authorized shielded payload container configurations such as the use of 55-gallon drums containing a pipe component (reference 9, section 2.9). In addition, S100, S200 pipe, and S300 overpacks shall meet the curie limits in section 3.3 of the $\mathrm{CH}$-TRAMPAC. Total dose 
equivalent rate and the neutron contribution to the total dose equivalent rate shall be reported for each payload container in the WWIS (reference 6, attachment B, table B-8).

\subsubsection{Decay Heat}

Acceptance Criterion. The decay heat plus its TMU (expressed in terms of one standard deviation) for each analytical category payload container plus its TMU-shall be less than or equal to the limit of the assigned shipping category specified in section 5.2.3 of the CH-TRAMPAC.

For CH-TRU waste from Los Alamos National Laboratory Teehnieal Area 54 assigned to Eontent Code LA 154, eomplianee with the deeay heat requirements is pursuant to appendix 6.12 of the CH-TRAMPAC. The decay heat plus its TMU (expressed in terms of one standard deviation) for high wattage $\mathrm{CH}$-TRU waste (Content Codes LA 154 and SQ 154) shipped in a TRUPACT-II shall be less than or equal to the decay heat limit specified in appendix 6.12 of the $\mathrm{CH}$-TRU Payload Appendices.

For all other approved Content Codes to be shipped in payload containers that exceed the decay heat limit of the assigned shipping category, a determination of compliance with the flammable gas/VOC limit as specified in the $\mathrm{CH}$-TRAMPAC allows the payload container to be shipped in the TRUPACT-II or HalfPACT package, respectively, under test category (also refer to section 3.5.5 in the $\mathrm{CH}$-WAC). The values calculated for decay heat and its associated TMU (expressed in terms of one standard deviation) shall be reported to the WWIS for each payload container.

The total deeay heat from all payload eontainers shall be less than 40 watts in a TRUPACT-II and less than 30 watts in a HalfPACT. (Reference 9, seetion 6.2.2)

\subsection{Physical Properties}

\subsubsection{Residual Liquids}

Acceptance Criterion. Liquid waste is prohibited at WIPP. Residual liquids containing PCBs are prohibited at WIPP. Waste shall contain as little residual liquid as is reasonably achievable by pouring, pumping, and/or aspirating-, and tinternal containers shall contain less than 1 inch or 2.5 centimeters of liquid in the bottom of the container. The total residual liquid in any payload container (e.g., 55-gallon drum, standard waste box, etc.) shall be less than 1 percent by volume of that container. If visual examination methods are used in lieu of radiography, then the detection of any liquids in nontransparent internal containers will be addressed by using the total volume of the internal container when determining the total volume of liquids within the payload container. (Reference 14, section 5.9.12; Reference 6, module II, section II.C.3.a; Reference 6, attachment B, sections B-1c and B-3c; Reference 9, section 2.6.1; Reference 17, appendix WCL; Reference 35, Conditions of Approval, II.A.2) 


\subsubsection{Sealed Containers}

Acceptance Criterion. Sealed containers that are greater than 4 liters (nominal) are prohibited except for Waste Material Type II.2 packaged in a metal container (reference 9 , section 2.8.1). All waste containers with unvented rigid containers greater than 4 liters (exclusive of rigid poly liners) shall be subject to innermost layer of containment sampling or shall be vented prior to initiating drum age and equilibrium criteria (reference 6 , attachment B1, section B1-1a). To satisfy both of these requirements, payload containers shall be verified to be free of sealed containers greater than 4 liters.

\subsection{Chemical Properties}

\subsubsection{Pyrophoric Materials}

Acceptance Criterion. Pyrophoric radioactive materials shall be present only in small residual amounts ( $<1$ percent by weight) in payload containers and shall be generally dispersed in the waste. Radioactive pyrophorics in concentrations $\geq 1$ percent by weight and all nonradioactive pyrophorics shall be reacted (or oxidized) and/or otherwise rendered nonreactive prior to placement in the payload container. Nonradionuclide pyrophoric materials are not acceptable at WIPP. (Reference 14, section 5.9.12; Reference 6, attachment B, section B-1c; Reference 6, module II, section II.C.3.b; Reference 9, section 4.1.1)

\subsubsection{Hazardous Waste}

Acceptance Criterion. Hazardous wastes not occurring as co-contaminants with TRU wastes (non-mixed hazardous wastes) are not acceptable at WIPP. Each $\mathrm{CH}$-TRU mixed waste container shall be assigned one or more hazardous waste codes as appropriate. Only EPA hazardous waste codes listed as allowable in the Hazardous Waste Facility Permit may be managed at WIPP. Some of the waste may also be identified by unique state hazardous waste codes. These wastes are acceptable at WIPP as long as the TSDF waste acceptance criteria are met (reference 6, attachment B, section B-1b; reference 6 , module II, section II.C.4). Wastes exhibiting the characteristic of ignitability, corrosivity, or reactivity (EPA hazardous waste numbers of D001, D002, or D003) are not acceptable at WIPP. In the context of this CH-WAC, hazardous waste codes are synonymous with hazardous waste numbers. (Reference 6 , attachment B, section B-1c; Reference 6, module II, sections II.C.3.c, II.C.3.g, and II.C.4)

\subsubsection{Chemical Compatibility}

Acceptance Criterion. TRU waste containing incompatible materials or materials incompatible with payload container and packaging materials, shipping container materials, other wastes, repository backfill, or seal and panel closure materials are not acceptable for transport in the TRUPACT-II and HalfPACT or for disposal at the WIPP. 
Chemical constituents shall conform to the lists of allowable materials in tables 4.3-1 through 4.3-8 of the $\mathrm{CH}$-TRAMPAC, as applicable. Other chemicals or materials not identified in these tables are allowed provided that they meet the requirements as specified in section 4.3.1 of the CH-TRAMPAC. (Reference 6, attachment B, section B1c; Reference 6, module II, section II.C.3.d; Reference 9, sections 4.3 and 4.4)

\subsubsection{Explosives, Corrosives, and Compressed Gases}

Acceptance Criterion. Waste shall contain no explosives, corrosives, or compressed gases (pressurized containers). (Reference 14, section 5.9.12; Reference 6, attachment B, section B-1c; Reference 6, module II, sections II.C.3.e and II.C.3.g; Reference 9, section 4.2.1)

\subsubsection{Headspace Gas Concentrations}

Acceptance Criterion. The headspace gas of payload containers shall be sampled and analyzed in accordance with an approved site-specific QAPjP, as defined in the WIPP WAP, to determine volatile organic compound (VOC) coneentrations. (Reference 6, attachment B, section B-1c; Referenee 6, module II, seetion II.C.3.i)

Flammable VOCs are restricted to $\leq 500 \mathrm{ppm}$ in the payload container headspace (reference 9, section 5.2). For those payload containers that exceed the flammable VOC limit, a determination of compliance with the flammable (gas/VOC) concentration limit as described in the $\mathrm{CH}$-TRAMPAC allows the payload container to be shipped under the test category. (Reference 9, section 5.2)

Test category payload containers shall be tested to determine if all applicable limits are met for hydrogen/methane, flammable VOCs, and total gas generation rates (as appropriate). (Reference 9, section 5.2)

\subsubsection{Polychlorinated Biphenyls}

Acceptance Criterion. TRU and TRU-mixed wastes which by virtue of their form and content may be disposed of in a chemical waste landfill may be disposed of at WIPP. For TRU and TRU-mixed wastes containing PCBs, the payload container data entered into the WWIS shall include the earliest date of waste generation (i.e., the date of removal from service for disposal), the date of waste certification for disposal, and the date the waste was sent to the WIPP for disposal (reference 35, section III.D.4). Additionally, the estimated weight of the PCBs in kilograms (as recorded on the uniform hazardous waste manifest) and a description of the type of PCB waste (e.g., PCB remediation waste, PCB bulk product waste, etc.) shall be entered into the WWIS (reference 36, §761.207(a)(2) and §761.180). Special handling requirements for shipping TRU and TRU-mixed wastes containing PCBs to WIPP necessitates that sites notify the WIPP Shipment Scheduler at least 10 days prior to its shipment date. In 
accordance with the revised WIPP Record of Decision, only Hanford, Idaho National Engineering and EnvironmentatLaboratory, Savannah River Site, Oak Ridge Reservation, Rocky Flats Environmental Technology Site, and Knolls Atomic Power Laboratory are authorized to ship their TRU and TRU-mixed wastes containing PCBs to WIPP (reference 37).

\subsection{Data Package Contents}

\subsubsection{Characterization and Certification Data}

Acceptance Criterion. Sites shall prepare a WSPF for each waste stream. Each WSPF shall be approved by the CBFO prior to the first shipment of that waste stream. Characterization and certification information for each payload container shall be submitted to the WWIS and approved by the Data Administrator. Sites are required to estimate the CPR weights and report these estimates in the WWIS on a payload container basis. Any payload container from a waste stream that has not been preceded by an appropriate certified WSPF is not acceptable at WIPP. (Reference 6, attachment $B$, section $B-4 b[2])$

\subsubsection{Shipping Data}

Acceptance Criterion. Sites shall prepare either a bill of lading or a uniform hazardous waste manifest for $\mathrm{CH}$-TRU waste shipments as required by the transportation requirements. The land disposal restriction notification for $\mathrm{CH}$-TRU mixed waste shipments shall state that the waste is not prohibited from land disposal. For shipment in the TRUPACT-II or the HalfPACT, the following documents shall be prepared for containers and assemblies, as appropriate: payload container transportation certification document; overpack payload container transportation certification document; and payload assembly transportation certification document. (Reference 6, attachment B, section B-4b(2); Reference 9, section 6) 


\subsection{QUALITY ASSURANCE REQUIREMENTS}

Quality assurance is an integral part of TRU waste characterization, certification, transportation, and operation activities. This section defines the QA program requirements that provide confidence that TRU waste characterization, certification, and transportation activities will be performed satisfactorily by each participating site. The QA requirements applicable to WIPP are addressed in the QAPD (reference 8).

Each site shall be responsible for developing, documenting, and implementing sitespecific QA plans that address the elements of the QAPD that apply to their TRU waste program. Specifically, sites shall develop QA plans that govern TRU waste characterization, certification, and transportation activities. These site-specific QA plans shall be submitted to the CBFO for approval. TRU wastes may not be characterized, certified, or shipped to WIPP before CBFO approval of these QA plans. The CBFO and the Management and Operating Contractor will conduct audits and surveillances to ensure that sites are in compliance with their approved site-specific QA plans.

\subsection{Waste Characterization Quality Assurance Requirements}

Sites are responsible for describing required $\mathrm{QA}$ and quality control $(\mathrm{QC})$ activities applicable to TRU waste characterization in site-specific QA documentation. All analytical laboratories analyzing WIPP waste characterization samples for the TRU waste sites shall have established, documented QA/QC programs.

Data quality objectives are qualitative and quantitative statements that specify WIPP program technical and quality objectives; they are determined through the data quality objective process (reference 30 ). The data quality objectives for waste characterization activities relating to the physical and chemical properties of the waste are contained in the WAP of the WIPP Hazardous Waste Facility Permit (reference 6, attachment B3). The radioassay data quality objectives are given in appendix $A$ of this document.

Any payload containers with unresolved discrepancies associated with hazardous waste characterization will not be managed or disposed of at WIPP until the discrepancies are resolved (reference 6, attachment B4, section B4-4). Corrective action reports applicable to WIPP WAP requirements shall be resolved prior to waste shipment (reference 6, attachment B6, section B6-4).

\subsection{Waste Certification Quality Assurance Requirements}

Participating sites shall develop and implement a site-specific QA plan for waste certification that describes the required QA and QC activities applicable to the certification of TRU waste to the CH-WAC. Site-specific QA plans must comply with the requirements of the QAPD (reference 8 ). 


\subsection{Waste Transportation Quality Assurance Requirements}

Quality assurance requirements for the transportation of TRU waste involve two elements: compliance with TRUPACT-II and HalfPACT payload control requirements and compliance with TRUPACT-II and HalfPACT usage requirements, as applicable. The QA requirements for payload control compliance are derived from the certificates of compliance for the TRUPACT-II and HalfPACT issued by the NRC (references 5 and 5a). The certificates of compliance reference the CH-TRAMPAC (reference 9). The QA requirements for compliance with TRUPACT-II and HalfPACT usage requirements are derived from 10 CFR Part 71 and 49 CFR Part 173 (references 15 and 28), the TRUPACT-II and HalfPACT certificates of compliance (references 5 and $5 \mathrm{a}$ ), DOE Orders 460.1 and 460.2 (references 31 and 32), and the $\mathrm{CH}$ Packaging Program Guidance (reference 20). Participating sites shall develop and implement site-specific QA plans that comply with these requirements. Sites are responsible for describing the QA and QC activities applicable to the specific parameters of the transportation packaging methods for payload control in a site-specific $\mathrm{CH}$-TRAMPAC. Sites shall develop and implement a transportation packaging QA program that defines the QA and QC activities applicable to usage of the TRUPACT-II and HalfPACT, as applicable. The use, operation, and maintenance of the TRUPACT-II and HalfPACT by the user are conducted under a QA program approved by the appropriate DOE field offices. This program controls the use of the NRC-certified packaging (TRUPACT-II and HalfPACT) and shall comply with the CH Packaging Program Guidance (reference 20). 


\subsection{REFERENCES}

NOTE: The current revision of these reference documents is applicable. The Internet links are provided for informational purposes only and may change.

1. Public Law 96-164, 93 Stat. 1259. National Security and Military Applications of Nuclear Energy Authorization Act of 1980, Section 213(a). (http://thomas.loc.gov/cgibin/bdquery/z?d096:SN00673:TOM:/bss/d096query.html)

2. Public Law 102-579, 106 Stat. 4777, 1992 (as amended by Public Law 104-201, 1996). Waste Isolation Pilot Plant Land Withdrawal Act. (http://www.emnrd.state.nm.us/wipp/lwa.htm)

3. 42 U.S.C. 6901 et seq. Resource Conservation and Recovery Act (RCRA) of 1988.

4. U.S. Department of Energy. Waste Isolation Pilot Plant Contact Handled (CH) Documented Safety Analysis. DOE/WIPP-95-2065. Carlsbad, New Mexico, Waste Isolation Pilot Plant, U.S. Department of Energy. (http://www.wipp.ws/library/chdsa/index.pdf)

5. U.S. Nuclear Regulatory Commission. Certificate of Compliance. NRC Docket No. 71-9218. Washington, D.C., Office of Regulatory Procedures, U.S. Nuclear Regulatory Commission.

(http://www.wipp.ws/library/CHsar/Documents/CH\%20PACKAGE\%20CofCs.pdf\# page=3)

5a. U.S. Nuclear Regulatory Commission. Certificate of Compliance. NRC Docket No. 71-9279. Washington, D.C., Office of Regulatory Procedures, U.S. Nuclear Regulatory Commission.

(http://www.wipp.ws/library/CHsar/Documents/CH\%20PACKAGE\%20CofCs.pdf\# page $=20$ )

6. New Mexico Environment Department. Waste Isolation Pilot Plant Hazardous Waste Facility Permit. NM4890139088-TSDF, Santa Fe, New Mexico. (http://www.wipp.ws/library/rcrapermit/rcrapermit.htm)

7. 63 FR 27353. Criteria for the Certification and Recertification of the Waste Isolation Pilot Plant's Compliance with the Disposal Regulations: Certification Decision: EPA Final Rule. Federal Register 63: 27353-27406, May 18, 1998, Radiation Protection Division, Washington, D.C. (http://www.epa.gov/radiation/wipp/reg.htm\#finalrule) 
8. U.S. Department of Energy. Quality Assurance Program Document. DOE/CBFO-94-1012. Carlsbad, New Mexico, Carlsbad Field Office, U.S. Department of Energy. (http://www.wipp.ws/library/qapd/qapd.pdf)

9. U.S. Nuclear Regulatory Commission. Contact-Handled Transuranic Waste Authorized Methods for Payload Control (CH-TRAMPAC). Washington, D.C., Office of Regulatory Procedures, U.S. Nuclear Regulatory Commission. (http://www.wipp.ws/library/CHsar/Documents/CH-TRAMPAC.pdf)

10. DOE (U.S. Department of Energy), 1980. Final Environmental Impact Statement for the Waste Isolation Pilot Plant, DOE/EIS-0026, October, Washington, D.C.

11. DOE (U.S. Department of Energy), 1990. Final Supplemental Environmental Impact Statement for the Waste Isolation Pilot Plant, DOE/EIS-0026-FS, January, Washington, D.C.

12. DOE (U.S. Department of Energy), 1997. Waste Isolation Pilot Plant Disposal Phase Final Supplemental Environmental Impact Statement, DOE/EIS-0026-S-2, September, Washington, D.C. (http://www.ws/library/seis/summary-104.pdf)

13. U.S. Department of Energy. WIPP Waste Information System User's Guide Manual. DOE/CBFO-97-2273. Carlsbad, New Mexico, Carlsbad Field Office, U.S. Department of Energy. (http://www.wipp.ws/wwis/WWISUsersGuideRev\%208.pdf)

14. U.S. Department of Energy. Waste Isolation Pilot Plant Contact Handled (CH) Technical Safety Requirements. DOE/WIPP-95-2125. Carlsbad, New Mexico, Waste Isolation Pilot Plant, U.S. Department of Energy. (http://www.wipp.ws/library/chdsa/CHTSRREV8.pdf)

15. Title 10 CFR Part 71. Packaging and Transportation of Radioactive Material. Code of Federal Regulations, Washington, D.C., Office of the Federal Register, National Archives and Records Administration. (http://www.gpoaccess.gov/cfr/index.html)

16. Title 40 CFR Part 194. Criteria for the Certification and Re-certification of the Waste Isolation Pilot Plant's Compliance with the 40 CFR Part 191 Disposal Regulations. Code of Federal Regulations, Washington, D.C., Office of the Federal Register, National Archives and Records Administration. (http://www.gpoaccess.gov/cfr/index.html)

17. U.S. Department of Energy. Title 40 CFR Part 191, Compliance Certification Application for the Waste Isolation Pilot Plant, DOE/CAO-1996-2184, 1996, Carlsbad, New Mexico. 
18. 42 U.S.C. 2011 et seq. Atomic Energy Act of 1954. (http://www.nrc.gov/reading-rm/doc-collections/nuregs/staff/sr0980/ml022200075vol1.pdf\#pagemode=bookmarks\&page=14)

19. 42 U.S.C 10141. Nuclear Waste Policy Act of 1982. (http://www.nrc.gov/reading-rm/doc-collections/nuregs/staff/sr0980/ml022200075vol1.pdf\#pagemode=bookmarks\&page $=277$ )

20. U.S. Department of Energy. CH Packaging Program Guidance, DOE/WIPP-023183. Carlsbad, New Mexico, Waste Isolation Pilot Plant, U.S. Department of Energy. (http://www.wipp.ws/library/t2omi/t2omi.htm)

21. National Institute of Standards and Technology, 1996. Specifications, Tolerances, and Other Technical Requirements for Weighing and Measuring Devices, NIST Handbook 44, National Institute of Standards and Technology, Office of Weights and Measures, Washington, D.C.

22. Title 49 CFR \$173.443. Contamination Control. Code of Federal Regulations, Washington, D.C., Office of the Federal Register, National Archives and Records Administration. (http://www.gpoaccess.gov/cfr/index.html)

23. Title 10 CFR Part 835. Occupational Radiation Protection. Code of Federal Regulations, Washington, D.C., Office of the Federal Register, National Archives and Records Administration. (http://www.gpoaccess.gov/cfr/index.html)

24. American National Standards Institute. ANSI/AIM BC1-1995, Uniform Symbology Specification - Code 39. American National Standards Institute, Inc., 1430 Broadway, New York, NY 10018.

25. U.S. Department of Energy. Radioactive Waste Management, DOE Order 435.1, Implementation Guide, Chapter III, Section III.L, page 103. (http://www.directives.doe.gov/pdfs/doe/doetext/neword/435/g4351-1ch3.pdf)

26. Title 40 CFR Part 262. Standards Applicable to Generators of Hazardous Waste. Code of Federal Regulations, Washington, D.C., Office of the Federal Register, National Archives and Records Administration. (http://www.gpoaccess.gov/cfr/index.html)

27. Title 40 CFR Part 191. Environmental Radiation Protection for Management and Disposal of Spent Nuclear Fuel, High-Level, and Transuranic Radioactive Wastes. 
Code of Federal Regulations, Washington, D.C., Office of the Federal Register, National Archives and Records Administration. (http://www.gpoaccess.gov/cfr/index.html)

28. Title 49 CFR Part 173. Shippers-General Requirements for Shipping and Packaging. Code of Federal Regulations, Washington, D.C., Office of the Federal Register, National Archives and Records Administration. (http://www.gpoaccess.gov/cfr/index.html)

29. Title 49 CFR Part 172. Shipping Papers: Additional Description Requirements. Code of Federal Regulations, Washington, D.C., Office of the Federal Register, National Archives and Records Administration. (http://www.gpoaccess.gov/cfr/index.html)

30. U.S. Environmental Protection Agency. Guidance for the Data Quality Objectives Process. EPA-QA/G-4, Washington, DC, Quality Assurance Management Staff, U.S. Environmental Protection Agency. (http://www.epa.gov/swerust1/cat/epaqag4.pdf)

31. U.S. Department of Energy. Packaging and Transportation Safety. DOE Order 460.1. Washington, D.C. (http://www.directives.doe.gov/pdfs/doe/doetext/neword/460/04601a.html)

32. U.S. Department of Energy. Departmental Materials Transportation and Packaging Management. DOE Order 460.2. Washington, D.C. (http://www.directives.doe.gov/pdfs/doe/doetext/neword/460/04602c1.html)

33. Public Law 108-137, Energy and Water Development Appropriations for Fiscal Year 2004, December 1, 2003.

34. U.S. Department of Energy. Waste Isolation Pilot Plant Initial Report for PCB Disposal Authorization. DOE/WIPP 02-3196. Carlsbad, New Mexico, Carlsbad Field Office, U.S. Department of Energy. (http://www.wipp.ws/rcradox/final/023196 PCB Initial 3-19-02 4-29-02.pdf)

35. U.S. Environmental Protection Agency, Letter and enclosed Conditions of Approval from Carl E. Edlund (Director, Multimedia Planning and Permitting Division, EPA) to Ines R. Triay (Manager, Carlsbad Field Office, DOE), dated May 15, 2003, granting approval for WIPP to dispose of TRU and TRU-mixed wastes containing PCBs. (http://www.wipp.ws/rcradox/final/WIPP-EPAapproval05-1503.pdf)

36. Title 40 CFR Part 761. Polychlorinated Biphenyls (PCBs) Manufacturing, Processing, Distribution in Commerce, and Use Prohibitions. Code of Federal 
Regulations, Washington, D.C., Office of the Federal Register, National Archives and Records Administration. (http://www.gpoaccess.gov/cfr/index.html)

37. 69 FR 39456. Revision to the Record of Decision for the Department of Energy's Waste Isolation Pilot Plant Disposal Phase. Federal Register 69: 39456-39459, June 30, 2004, Department of Energy, Washington, D.C. (http://www.em.doe.gov/vgn/images/portal/cit 1819/26/31/92604PCB\%20ROD\%2 0Fed\%20Reg\%20063004\%20p39456-9.pdf) 


\section{APPENDIX A}

\section{Radioassay Requirements for Contact-Handled Transuranic Waste}




\section{A.1 Introduction}

The Waste Isolation Pilot Plant (WIPP) requires radiological characterization data to:

- track the WIPP radionuclide inventory, by isotopic activity and mass, for those radionuclides listed in section 3.3.1,

- demonstrate that each payload container disposed of at the WIPP contains TRU waste as specified in section 3.3.3, and

- verify that applicable transportation and facility limits on individual payload containers and assemblies for FGE, PE-Ci, and decay heat are not exceeded, as specified in section 3.3.2, 3.3.4 and 3.3.6.

The radioassay process quantifies at least one of the more prevalent radionuclides known to be present in the waste. The remaining listed radionuclides present in the waste in significant quantities will be identified by direct measurement of isotopic ratios as discussed in section A.2. The isotopic ratios are then used to quantify radionuclides based on the assay value.

The requisite data on isotopic ratios and quantities will be derived from $A K$ (see section A.2), radioassay or both using CBFO approved nondestructive assay (NDA) or RC techniques, instruments and procedures. Each site must technically justify that the AK and/or radioassay techniques, instruments and procedures used:

- are appropriate for the specific waste stream and waste content code descriptions being assayed, and

- will result in unbiased values for the cumulative activity and mass of the WIPP radionuclide inventory.

Existing radioassay data collected prior to the implementation of a quality assurance program pursuant to 40 CFR $\$ 194.22(a)(1)$ may only be qualified in accordance with an alternate methodology that is approved by CBFO and employs one or more of the following methods:

- peer review in accordance with NUREG-1297 (reference A1),

- corroborating data,

- confirmatory testing (i.e., testing made on a representative sub-population of payload containers within a waste stream), or 
- demonstrating the equivalence of an alternate QA program (as described in reference $A 2$, section 5.4).

Proposals for alternative approaches to identification and quantification of radioisotopes (e.g., quantification of isotopic ratio AK on a waste stream basis) must be submitted to CBFO for review and approval. CBFO will report such proposals to EPA for consideration prior to issuing approval.

Controlled changes to radioassay (NDA or radiochemistry) related plans or procedures shall be managed through the document control process described in the QAPD. The Site Project Manager and the Site QA Officer shall review all such changes and report to the CBFO those changes that could impact compliance with the criteria in this document. The Site Project Manager shall ensure that site approved changes to radioassay related plans or procedures affecting either the performance criteria or data quality of certified systems/processes are not used in the collection of waste certification data prior to CBFO's review and approval. Related testing, calibration, and training performed in accordance with these site-approved changes, however, are not precluded from being conducted prior to CBFO's review and approval. (Memorandum from CBFO to Distribution, CBFO:NTP:RMK:VW:02-2734:UFC:5822, July 29, 2002.)

\section{A.2 Radionuclide Isotopic Ratios}

Establishing isotopic ratios for use in quantifying radionuclides is performed by direct measurement of the containers using WIPP-certified systems. Sites may opt to qualify AK as permitted by 40 CFR $\$ 194.22$ (b) by performing confirmatory testing using WIPPcertified radioassay systems. When a site performs direct measurements of isotopic ratios, it is expected that all containers in the waste stream will be measured, with the understanding that, in some cases, valid data may not be obtainable for given containers for technical reasons (e.g., lack of sufficient signal or poor counting statistics). All such instances will be documented and appropriately dispositioned by the measurement facility. For those few waste containers for which direct measurement does not yield useable isotopic ratio information, AK may be used.

\section{A.2.1 Methods for Confirmation of Isotopic Ratio AK}

As a minimum, to confirm existing AK data, it is necessary to compare ratios of the two most prevalent radionuclides in the isotopic mix. For weapons and reactor grade plutonium, these are typically ${ }^{239} \mathrm{Pu}$ and ${ }^{240} \mathrm{Pu}$. For heat source waste, the predominant radionuclides are typically ${ }^{238} \mathrm{Pu}$ and ${ }^{239} \mathrm{Pu}$. Measured isotopic ratios for ${ }^{241} \mathrm{Am}$ may confirm existing AK by waste stream. However, due to the fluctuation of ${ }^{241} \mathrm{Am}$ in certain waste streams, it may become necessary to measure ${ }^{239} \mathrm{Pu}$ to ${ }^{241} \mathrm{Am}$ isotopic ratios on all containers in that waste stream. 
${ }^{241} \mathrm{Am}$ is the daughter of ${ }^{241} \mathrm{Pu}$, which decays with a half-life of about 14 years. If the time since the chemical separation of the plutonium is known, the quantity of measured ${ }^{241} \mathrm{Am}$ can be used to calculate the quantity of ${ }^{241} \mathrm{Pu}$. This assumes there was no ${ }^{241} \mathrm{Am}$ in the waste just after the chemical separation and that no ${ }^{241} \mathrm{Am}$ was added to or removed from the waste during the time since the separation. Since ${ }^{241} \mathrm{Am}$ is an indirect measurement of ${ }^{241} \mathrm{Pu}$, it could be compared (by ratio) to any plutonium isotope $\left({ }^{239} \mathrm{Pu}\right.$ or ${ }^{240} \mathrm{Pu}$ ) associated with weapons and reactor grade plutonium.

For weapons grade and reactor grade waste, isotopic ratio values for ${ }^{238} \mathrm{Pu}$ can be assumed to be valid in AK data if the values for ${ }^{239} \mathrm{Pu}$ and ${ }^{240} \mathrm{Pu}$ have been confirmed. Because ${ }^{242} \mathrm{Pu}$ cannot be measured using NDA methods, the contribution of ${ }^{242} \mathrm{Pu}$ isotopic ratio is calculated by correlation techniques.

For some of the generator sites that were involved primarily in weapons production, the fissile isotopes ${ }^{235} \mathrm{U}$ and ${ }^{233} \mathrm{U}$ and the fissionable isotope ${ }^{238} \mathrm{U}$ may not have been measured when the transuranic waste was originally assayed (i.e., using non-WIPPcertified systems), primarily because the plutonium isotopes were the radionuclides of interest to the generator site. However, other forms of AK may be available. If so, then the AK can be confirmed by data generated on a WIPP-certified system. If valid AK does not exist, then the data generated on a WIPP-certified system can only be used to detect or calculate ${ }^{238} \mathrm{U},{ }^{235} \mathrm{U}$, and ${ }^{233} \mathrm{U}$ or to confirm their absence. Because ${ }^{234} \mathrm{U}$ cannot be measured using NDA methods, the isotopic ratios for ${ }^{234} U$ may be calculated from the ${ }^{235} \mathrm{U}$ enrichment. Values, or lack thereof, for ${ }^{137} \mathrm{Cs}$ can be confirmed by the data generated on a WIPP-certified system. This is typically done by measuring ${ }^{137} \mathrm{Cs}$ directly, or by comparing the NDA measured ${ }^{241} \mathrm{Am} 662$ kiloelectron volt (keV) peak to the other ${ }^{241} \mathrm{Am}$ peaks (e.g., the $125 \mathrm{keV}$ or $721 \mathrm{keV}$ peaks) to determine if the $662 \mathrm{keV}$ peak's intensity is consistent with the expected ${ }^{241} \mathrm{Am}$ intensity. A disproportionate response for the $662 \mathrm{keV}$ peak relative to the other ${ }^{241} \mathrm{Am}$ peaks may indicate the presence of ${ }^{137} \mathrm{Cs}$. ${ }^{90} \mathrm{Sr}$ may be calculated from the value for ${ }^{137} \mathrm{Cs}$ and $\mathrm{AK}$. If detected, a waste container's concentration of ${ }^{137} \mathrm{Cs}$ can be used to derive a value of ${ }^{90} \mathrm{Sr}$, through the application of the appropriate scaling factor(s). All scaling factors used will be technically sound and based on known, documented relationships or correlations. The data report for the waste containers for which the ${ }^{90} \mathrm{Sr}$, value is derived in this manner shall reflect the use of a scaling factor(s) and provide sufficient documentation to enable its independent calculation. Finally, the gamma spectra must be carefully examined for significant presence of other radionuclides to ensure compliance with transportation requirements. Data obtained for radionuclides other than the WIPP-tracked radionuclides presented above are required to address confounding isotope issues (i.e., masking) with regard to NDA. When radiochemistry is used for confirmation radioassay instead of NDA, less reliance on calculated isotopics is required.

Each site must technically justify that the techniques used to confirm the absence or the ratio of non-measurable radionuclides are valid for the particular radioassay method used to confirm AK. 


\section{A.2.2 Acceptable Knowledge (AK) Documentation}

The use of $A K$ information concerning the radiological composition of a waste stream will be documented either in the AK summary report for the waste characterization of the waste stream or in another controlled document approved by the Site Project Manager. Should this information be contained in AK package(s) prepared to meet other general waste characterization requirements, it need not be duplicated in other controlled documents that address the radiological properties of the waste stream; however, all relevant information must be included in the AK record. The following discussion is included for the sake of completeness.

\section{A.2.2.1 Required Elements}

This section identifies the required radiological information that each TRU waste generating site or measurement facility must maintain for a waste stream. A TRU waste generator site or waste characterization facility may use AK to delineate the distribution of the 10 WIPP-tracked radioisotopes within a TRU waste stream and the presence or absence of isotopes. The type and quantity of supporting documentation may vary by waste stream and shall be compiled in a written record that shall include a summary identifying all sources of information used to delineate the waste stream's isotopic distribution. The basis and rationale for the delineation shall be clearly summarized in an AK report and traceable to referenced documents. Assumptions made in this delineation shall be identified. The following information shall be included as part of the AK written record:

- map of the site with the areas and facilities involved in TRU-mixed waste generation, treatment, and storage identified

- facility mission description as related to radionuclide-bearing materials and their management, e.g., routine weapons production, fuel research \& development and experimental processes

- description of the specific site locations (such as the area or building) and operations relative to the isotopic composition of the TRU wastes they generated, e.g., plutonium recovery, weapons fabrication, pyrochemical operations and waste incineration

- waste identification or categorization schemes used at the facility relevant to the waste material's isotopic distribution, e.g., the use of codes that correlate to a specific isotopic distribution, and a description of the isotopic composition of each waste stream 
- information regarding the waste's physical and chemical composition that could affect the isotopic distribution, e.g., processes used to remove ingrown ${ }^{241} \mathrm{Am}$ or alter its expected contribution based solely on radioactive decay kinetics

- statement of all numerical adjustments applied to derive the material's isotopic distribution, e.g., scaling factors, decay/ingrowth corrections and secular equilibrium considerations

- specification of the isotopic ratios for the 10 WIPP-tracked radionuclides $\left({ }^{241} \mathrm{Am}\right.$, ${ }^{238} \mathrm{Pu},{ }^{239} \mathrm{Pu},{ }^{240} \mathrm{Pu},{ }^{242} \mathrm{Pu},{ }^{233} \mathrm{U},{ }^{234} \mathrm{U},{ }^{238} \mathrm{U},{ }^{90} \mathrm{Sr}$, and ${ }^{137} \mathrm{Cs}$ ) and, if applicable, the radionuclides that comprise $95 \%$ of the radiological hazard on a waste stream, waste stream subpopulation, or container basis.

\section{A.2.2.2 Supplemental Acceptable Knowledge Information}

Each generator site or measurement facility shall obtain supplemental AK information, dependent on availability. The amount and type of this information cannot be mandated, but sites shall collect information as appropriate to support their contention regarding the waste's isotopic distribution. This information will be used to compile the waste's AK written record. Supplemental AK documentation that may be used includes, but is not limited to, information from the following sources:

- Safeguards \& Security, Materials Control \& Accountability and other nuclear materials control systems or programs and the data they generated

- reports of nuclear safety or criticality, or accidents/excursions involving the use of special nuclear material (SNM) or nuclear material

- waste packaging, waste disposal, building or nuclear material management area logs or inventory records, and site databases that provide information on SNM or nuclear materials

- test plans, research project reports or laboratory notebooks that describe the radionuclide content of materials used in experiments

- information from site personnel (e.g., documented interviews)

- historical analytical data relevant to the isotopic distribution of the waste stream

\section{A.2.2.3 Discrepancy Resolution}

If there is a discrepancy between AK information related to isotopic ratios or composition, the site will evaluate the sources of the discrepancy to determine if the discrepant information is credible. Information that is not credible or information that is limited in its 
applicability to WIPP characterization will be identified as such and the reasons for dismissing it will be justified in writing. Limitations concerning the information will be documented in the AK record and summarized in the AK report. In the event that the discrepancy cannot be resolved, the site will perform direct measurements for the impacted population of containers.

If discrepancies result in a change to the original determinations, the AK summary will be updated.

\section{A.3 Data Quality Objectives}

The data quality objectives for WIPP certifiable radiological characterization data are established in section 3.3 of the $\mathrm{CH}-\mathrm{WAC}$. They are summarized below in table A-3 as they apply to individual payload containers.

Table A-3

Data Quality Objectives for Radioassay

\begin{tabular}{|c|c||c|}
\hline Requirement & DQO & Confidence $^{\mathrm{a}}$ \\
\hline $\begin{array}{c}\text { TRU } \alpha \text {-activity concentration }>100 \\
\mathrm{nCi} / \mathrm{g}^{\mathrm{b}}\end{array}$ & $\mathrm{A}>\mathrm{LLD}$ & $\mathrm{N} / \mathrm{A}$ \\
\hline Fissile mass $\leq$ FGE limit & $\begin{array}{c}\mathrm{FGE}+2 \sigma_{\mathrm{TMU}}(\mathrm{FGE}) \leq \mathrm{FGE} \\
\text { limit }\end{array}$ & $97.5 \%$ \\
\hline Decay heat $\leq \mathrm{CH}$-TRAMPAC limit & $\mathrm{DH}+1 \sigma_{\mathrm{TMU}}(\mathrm{DH}) \leq \mathrm{L}_{\mathrm{CH}-\mathrm{TRAMPAC}}$ & $84 \%$ \\
\hline
\end{tabular}

${ }^{a}$ Confidence means the statistical level of confidence that the limit is exceeded or not exceeded depending on the requirements of the individual data quality objectives. The confidence is derived from the specified DQOs which assume contributions to TMU are normally distributed.

${ }^{\mathrm{b}}$ TRU waste determinations shall be in accordance with the policy for the management of TRU alpha activity concentration when overpacking waste containers (see appendix E).

There are no stipulated data quality objectives for PE-Ci or individual isotope activities (except as they impact the requirements listed above). However, at a minimum, radioassay programs must be capable of identifying, measuring, and reporting the presence or absence of:

- the ten radionuclides identified in section 3.3.1 for tracking of the WIPP radionuclide inventory (see section A.2.1),

- ${ }^{235} \mathrm{U}$, in order to calculate $\mathrm{FGE}$, as required in section 3.3.2 for compliance with transportation requirements, and

- other radionuclides whose presence contribute to $95 \%$ of the radioactive hazard, as specified in section 3.3.1, for compliance with transportation requirements. 
In support of the above requirements, each site must evaluate, document and technically justify the following determinations.

Lower Limit of Detection: The lower limit of detection (LLD) for each radioassay system must be determined. Instruments performing TRU/low-level waste discrimination measurements must have an LLD of $100 \mathrm{nCi} / \mathrm{g}$ or less. Site specific environmental background and container specific interferences must be factored into LLD determinations. The LLD is that level of radioactivity which, if present, yields a measured value greater than the critical level with a $95 \%$ probability, where the critical level is defined as that value which measurements of the background will exceed with $5 \%$ probability. Because the LLD is a measurement-based parameter, it is not feasible to calculate LLDs for radionuclides that are not determined primarily by measurement, e.g., ${ }^{90} \mathrm{Sr}$. In such cases, the site shall derive the equivalent of an LLD, i.e., a reporting threshold for a radionuclide(s), when it is technically justified. This value may be based on decay kinetics, scaling factors or other scientifically based relationships and must be adequately documented in site records. For purposes of reporting radionuclide data in the WWIS, this value will be the equivalent of an LLD. References A3 and A4 provide information in developing the LLD.

Total Measurement Uncertainty (TMU): The method used to calculate the TMU for the quantities in table A-3 must be documented and technically justified for each CBFO certified radioassay system. Compliance with this requirement will be evaluated in reviews of the TMU documentation package for each assay system by CBFO. General guidance for determining the TMU is provided in references $\mathrm{A} 5$ and $\mathrm{A6}$.

Calibration Procedures and Frequencies: Each radioassay measurement system shall be calibrated before initial use. During calibration or re-calibration, system correction factors shall be established and algorithms adjusted such that the value of $\% \mathrm{R}$ is set equal to $100 \%$; i.e., the system is calibrated to $100 \%$ R. The range of applicability of system calibrations must be specified in site procedures. The matrix/source surrogate waste combination(s) used for calibration shall be representative of the

- activity range(s) or gram loading(s), and

- relevant waste matrix characteristics (e.g., densities, moderator content, container size) planned for measurement by the system.

Calibration(s) shall be performed in accordance with consensus standards, when such standards exist. If consensus standards are not used, full documentation of the calibration technique must be provided to and approved by CBFO prior to performing WIPP related assays. Primary calibration standards shall be obtained from suppliers maintaining a nationally accredited measurement program. When primary standards are not available, the standards used shall be correlated with primary standards obtained 
from a nationally accredited measurement program. For calorimetry, calibration shall be performed in accordance with reference A9.

Calibration Verification: Notwithstanding the need to calibrate individual components for replacement, changes or adjustments (e.g., energy calibration of a detector), verification of the radioassay measurement system's calibration shall be performed after any one of the following occurs:

- major system repairs and/or modifications

- replacement of the measurement system's components, e.g., detector, neutron generator or supporting electronic components that have the capacity to affect data

- significant changes to the system's software

- relocation of the system

Calibration verification shall consist of demonstrating that the system is within the range of acceptable operation. Secondary standards can be used for the calibration verification if their performance has been correlated with the calibration standard. If a verification of the measurement system's calibration or other test demonstrates that the system's response has significantly changed, a re-calibration of the system shall be performed.

Calibration Confirmation: In order to confirm that the calibration of the NDA system was correctly established, the accuracy and precision of the system are determined after each calibration or re-calibration by performing replicate measurements of a noninterfering matrix. Calibration confirmation replicate measurements shall be performed on containers of the same nominal size as those in which actual waste is assayed and according to approved waste assay procedures. The number of replicate measurements to be performed shall be documented and technically justified. The replicate measurements shall be performed using nationally recognized standards, or certified standards derived from nationally recognized standards that span the range of use. The standards used to calculate accuracy shall not be the same as those used for the system calibration. Accuracy is reported as percent recovery $(\% \mathrm{R})$. The applicable range for accuracy shall not exceed $\pm 30 \%$ on a non-interfering matrix. Precision is reported as percent relative standard deviation (\% RSD). The \%RSD shall not exceed the values listed in table A-3.2 for the corresponding number of replicate measurements in a noninterfering matrix. 
Table A-3.2

Upper Limits for \%RSD vs. Number of Replicates

\begin{tabular}{|l|c|c|c|c|c|c|c|c|c|c|c|c|c|c|}
\hline $\begin{array}{l}\text { Number of } \\
\text { Replicates }\end{array}$ & 2 & 3 & 4 & 5 & 6 & 7 & 8 & 9 & 10 & 11 & 12 & 13 & 14 & 15 \\
\hline Max \%RSD & 1.8 & 6.6 & 10.0 & 12.3 & 14.0 & 15.2 & 16.2 & 17.1 & 17.7 & 18.3 & 18.8 & 19.3 & 19.7 & 20.0 \\
\hline
\end{tabular}

${ }^{a}$ The values listed are derived from the measured standard deviation of the replicate measurements using $\frac{s}{\mu} \cdot 100 \%<\sqrt{\frac{(0.292) \cdot \chi_{0.05, n-1}^{2}}{n-1}} \cdot 100 \%$ where $\mathrm{s}$ is the measured standard deviation, $\mathrm{n}$ is the number of

replicates, $\mu$ is the true value, $\quad \chi_{0.05, n-1}^{2}$ is the critical value for the upper $5 \%$ tail of a one sided chisquared distribution with $n-1$ degrees of freedom, and 0.292 corresponds to a $95 \%$ upper confidence bound on the true system precision limit of $29.2 \%$.

Measurement facilities may develop alternate limits for accuracy and precision subject to approval by CBFO prior to certification of waste.

\section{A.4 Quality Control}

To ensure that data of known and documented quality are generated, each participating measurement facility shall implement a documented facility QA program. Any radioassay technique used for TRU waste must be performed in accordance with calibration and operating procedures that have been written, approved, and controlled by the site or testing facility. Laboratory procedures must contain applicable quality controls. Facility QA programs shall specify qualitative and quantitative acceptance criteria for the QC checks of this program and corrective action measures to be taken when these criteria are not satisfied.

\section{A.4.1 General Requirements}

Radioassay Training: Only appropriately trained and qualified personnel shall be allowed to perform radioassay and data validation/review. Standardized Training requirements for radioassay personnel shall be based upon existing industry standardized training requirements (e.g., ASTM C1490, Standard Guide for Selection, Training and Qualification of Nondestructive Assay (NDA) Personnel (reference A8); ANSI N15.54, Radiometric Calorimeters - Measurement Control Program (reference A9)) and shall meet the specifications in the QAPD. Requalification of radioassay personnel shall be based upon evidence of continued satisfactory performance and must be performed at least every two years.

Software QC Requirements: All computer programs and revisions thereof used for radioassay shall meet the applicable requirements in the QAPD (reference $A 2$, section $6.0)$. 
Comparison Programs: Sites using radioassay systems shall participate in any relevant measurement comparison program(s) sponsored or approved by the CBFO. Such programs may be conducted as part of the NDA performance demonstration program (references A7 and A10) or through other third parties. (Reference: WIPP Compliance Certification Application including Annual Reports to the EPA)

\section{A.4.2 NDA QC Requirements}

The assay procedures cited in various American Society for Testing and Materials (ASTM) and American National Standards Institute (ANSI) standards (references A9, A11-A15) and NRC standard practices and guidelines (reference A16) as referenced in this appendix are recommended for use at all testing facilities.

Background Measurements: Background measurements must be performed and recorded daily, unless otherwise approved by CBFO. Contributions to background due to radiation from nearby radiation producing equipment, standards or wastes must be carefully controlled or more frequent background checks must be performed. For calorimeters, basepower or baseline measurements shall be conducted at a frequency determined by each site and approved by CBFO.

Instrument Performance Measurements: Performance checks on calibrated and operable gamma and neutron NDA instruments must be performed and recorded once per operational day. Performance checks shall include efficiency checks (when applicable), matrix correction checks and, for spectrometric instruments, peak position and resolution checks.

Both radioactive sources and surrogate waste matrix containers (both non-interfering and interfering) are used. At least once per operational week an interfering matrix must be used to assess the long-term stability of the NDA instrument's matrix correction. Surrogate waste containers must reflect the type of waste, e.g., debris, sludge, currently being assayed. To verify calibration, radioactivity standards must be selected such that, over a six month period, the operating range of the assay system is tested in each applicable surrogate waste matrix. The use of interfering and non-interfering matrices provides a realistic assessment of the assay system's performance over time, and will assist measurement personnel in detecting potential problems relative to the matrices currently assayed by the measurement system.

Interfering surrogate matrix containers must be constructed in such a way that the waste characteristics do not change over time.

Radioactive sources should be long-lived, easy to position relative to the detector(s), and of sufficient radioactivity to obtain good results with relatively short count times. 
Performance checks for calorimetry shall be performed with electrical and/or heat standards traceable to a nationally accredited measurement program at a frequency determined by each site, consistent with reference A17. This information is specified in site operating procedures and approved by CBFO.

Data Checks: Background (for calorimetry: baseline or base power) and performance measurements shall be reviewed and evaluated at least weekly to determine continued acceptability of the assay system and to monitor performance trends. If daily performance checks result in data that are outside the acceptable range, the required responses in table A-4.2 shall be followed.

Table A-4.2 Range of Applicability

\begin{tabular}{|c|c|c|}
\hline Category & $\begin{array}{c}\text { Acceptability } \\
\text { Range }^{\mathrm{a}}\end{array}$ & Required Response \\
\hline Acceptable Range & $\mid$ Data $\left.\right|^{\mathrm{c}} \leq 2 \sigma^{\mathrm{b}}$ & No action required. \\
\hline Warning Range & $2 \sigma^{b}<\mid$ Data $\mid \leq 3 \sigma^{b}$ & $\begin{array}{l}\text { The performance check standard shall be rerun no more } \\
\text { than two times. If the rerun performance check(s) result } \\
\text { in data within } \pm 2 \sigma \text {, then the additional performance } \\
\text { checks shall be documented and work may continue. If } \\
\text { the system does not fall within } \pm 2 \sigma \text { after two rerun } \\
\text { performance checks, then the required response for the } \\
\text { Action Range shall be followed. }\end{array}$ \\
\hline Action Range & $\mid$ Data $\mid>3 \sigma^{b}$ & $\begin{array}{l}\text { Work shall stop and the occurrence shall be documented } \\
\text { and appropriately dispositioned (e.g., initiating a non- } \\
\text { conformance report). The radioassay system shall be } \\
\text { removed from service pending successful resolution of all } \\
\text { necessary actions, and all assays performed since the } \\
\text { last acceptable performance check are suspect, pending } \\
\text { satisfactory resolution. Recalibration or calibration } \\
\text { verification is required prior to returning the system back } \\
\text { to service. }\end{array}$ \\
\hline \multicolumn{3}{|c|}{$\begin{array}{l}\text { a Reference A15 } \\
\mathrm{b} \text { " } \sigma \text { " - the standard deviation is only based on the reproducibility of the data check measurements } \\
\text { themselves. This is not TMU. } \\
\text { 'Absolute Value }\end{array}$} \\
\hline
\end{tabular}

\section{A.4.3 Radiochemistry QC Requirements}

Any RC method may be used as long as the assay results meet the DQOs specified in section A.3. Each laboratory used for TRU waste assay by RC shall demonstrate that the analytical methods are appropriate to assay the specific wastes for which they are proposed. These methods must contain the following general provisions:

- Assay standards must be prepared and used as indicated in the standard test methods. 
- The sample taken from the waste must be representative and traceable to its specific waste batch or waste container.

- The test result for each sample must be associated with a specific lot, batch number, or container.

All methods will be preceded by radiochemical separation and/or preparation for measurement. Table A-4.3 presents a list of laboratory control procedures that must be performed by laboratories involved in the TRU waste RC process.

Table A-4.3

Quality Control Requirements for Radiochemistry

\begin{tabular}{|c|c|c|c|}
\hline QC Sample & Minimum Frequency & Acceptance Criteria & Corrective Action \\
\hline $\begin{array}{l}\text { Laboratory control } \\
\text { samples (LCS) }\end{array}$ & One per analytical batch & $75 \%$ to $125 \% \mathrm{R}$ & $\begin{array}{l}\text { See Laboratory Control } \\
\text { Sample }^{\mathrm{a}}\end{array}$ \\
\hline Method blank & One per analytical batch & $\begin{array}{l}\text { Site-specific statistical } \\
\text { control limits }\end{array}$ & See Method Blanks ${ }^{b}$ \\
\hline Laboratory duplicate & One per analytical batch & $\begin{array}{l}\text { RPD (relative percent } \\
\text { difference) } \leq 40, \text { or } \\
\text { project-specific } \\
\text { requirements }\end{array}$ & $\begin{array}{l}\text { See Laboratory } \\
\text { Duplicate }^{c}\end{array}$ \\
\hline Matrix spike (MS) & $\begin{array}{l}\text { One per analytical batch } \\
\text { for ICP-MS, as required } \\
\text { by the test performed }\end{array}$ & 50 to $150 \% \mathrm{R}$ & $\begin{array}{l}\text { See Matrix Spike and } \\
\text { Matrix Spike Duplicate }\end{array}$ \\
\hline $\begin{array}{l}\text { Matrix spike duplicate } \\
\text { (MSD) }\end{array}$ & $\begin{array}{l}\text { One per analytical } \\
\text { batch, as required by } \\
\text { the test performed }\end{array}$ & $\begin{array}{l}\quad 50 \text { to } 150 \% R \\
\quad \mathrm{RPD} \leq 40, \\
\text { or project-specific } \\
\text { requirements }\end{array}$ & $\begin{array}{l}\text { See Matrix Spike and } \\
\text { Matrix Spike Duplicate }\end{array}$ \\
\hline Radioisotopic tracers & Every sample & $\begin{array}{l}\text { Site-specific statistical } \\
\text { control limits }\end{array}$ & $\begin{array}{l}\text { See Radioisotopic } \\
\text { Tracer }^{\mathrm{e}}\end{array}$ \\
\hline
\end{tabular}

aLaboratory Control Sample (LCS): An LCS is analyzed at least once per analytical batch. If a solid matrix with established control limits is used as the LCS, the established limits may be used for the acceptance criteria. If LCS recoveries do not meet acceptance criteria, a non-conformance report is prepared and corrective action is initiated to determine the cause of the problem. Associated samples are qualified in the data report.

${ }^{b}$ Method Blanks: A method blank is analyzed at least once per analytical batch. It contains all reagents in proportions equal to those in the samples and is carried through the analytical procedure to identify if contamination is present. Each site establishes the acceptance criteria for method blanks; they may be expressed as statistical control limits. Criteria may be absolute values, multiples of background variation, fractions of activity concentrations observed in samples, or other appropriate units. When results outside the criteria are obtained, a non-conformance report is prepared and corrective action is initiated to determine the cause of the problem. Associated samples are qualified in the data report. 


\begin{abstract}
${ }^{\mathrm{C}}$ Laboratory Duplicate. A laboratory duplicate is analyzed at least once per analytical batch. A laboratory duplicate is a separate aliquot from the same field sample carried through the entire analytical procedure. The RPD between duplicate results is compared with the criteria; if the RPD between duplicate results does not meet the criteria, a non-conformance report is prepared and corrective action is initiated to determine the cause of the problem. Associated sample results are qualified in the data report.
\end{abstract}

\begin{abstract}
${ }^{d}$ Matrix Spike and Matrix Spike Duplicate: Duplicate MSs on individual field samples are performed for inductively coupled plasma-mass spectrometry (ICP-MS) analysis at a minimum frequency of one pair (MS plus MSD) per analytical batch. The MSDs are preferred for any analytical procedure not using radioactive tracers. The MS and MSD results are acceptable if the criteria given above for percent recovery and RPD are met. Sample data associated with non-compliant MS and MSD results are qualified in the data report.
\end{abstract}

${ }^{\text {e}}$ Radioisotopic Tracer: Some methods require that all samples, blanks, LCSs, and laboratory duplicates be spiked with radioisotopic tracers to determine chemical recoveries, counting efficiencies, or a combination thereof. Each site establishes the acceptance criteria for method blanks; they may be expressed as statistical control limits. When yields outside the criteria are obtained, a non-conformance report is prepared and corrective action is initiated to determine the cause of the problem. Associated samples are qualified in the data report.

Completeness of RC data shall be expressed as the ratio of the number of samples that are analyzed with valid results to the total number of samples that are submitted for analysis, expressed as a percent. Acceptable RC data shall be obtained for 90 percent of the samples acquired for waste characterization. Valid results for radioassay data are those that were obtained when the laboratory or testing facility demonstrated that the instrumentation and method were in control.

Representativeness of RC data shall be achieved by the collection of unbiased samples.

\title{
A.5 Data Management
}

\section{A.5.1 Data Review and Validation}

All radioassay data must be reviewed and approved by qualified personnel prior to being reported. At a minimum, the data must be reviewed by a technical reviewer and approved by the site project manager or their designee(s). The validation process includes verification that the applicable quality controls specified in section A.4 have been met.

\section{A.5.2 Data Reporting}

Radioassay data must be reported to the site project office on a testing batch basis. Batches are defined, for the purpose of the program, as a suite of waste containers undergoing radioassay using the same testing equipment. For NDA, the sites shall specify the size of the testing batch as needed, without regard to waste matrix. For RC, a testing batch shall not exceed 20 waste containers without regard to waste matrix, as is consistent with industry practice.

Each radioassay testing facility is required to submit testing batch data reports for each testing batch to the site project office on standard forms (either hard copy or electronic 
equivalent), as provided in approved site specific documentation. Radioassay testing batch data reports shall consist of the following:

- testing facility name, testing batch number, container numbers included in that testing batch, and signature release by the site project manager or their designee(s).

- table of contents

- background and performance data or control charts for the relevant time period.

- data validation per the QAPD (reference A2, section 5.3.2) and as described in site procedures.

- separate testing report sheet(s) for each container in the testing batch that includes

- title "Radioassay Data Sheet"

- method used for radioassay (i.e., procedure identification)

- date of radioassay

- activities and/or masses of individual radioisotopes present and their associated TMUs (curies and/or grams)

- operator signature/date

- reviewer signature/date

Other radiological properties to be documented for each container include:

- decay heat expressed in Watts (W) and its associated TMU,

- total ${ }^{239} \mathrm{Pu}$ FGE expressed in grams (g) and its associated TMU,

- TRU alpha activity concentration expressed in curies/gram (Ci/g) and its associated TMU, and

- total ${ }^{239} \mathrm{Pu}$ equivalent activity expressed in curies (Ci).

These calculated quantities shall be included in the radioassay batch data report or other $\mathrm{QA}$ record or database.

When TMU is reported differently on the testing report sheet than in WWIS, the method of expressing TMU shall be specified on the testing report sheet or associated procedures/QAPjP. In the case of radiochemical analyses, the batch data report shall also include the QC sample results. 


\section{A.5.3 Data and Records Retention}

The following nonpermanent records shall be maintained at the radioassay-testing facilities or shall be forwarded to the site project office for maintenance, and shall be documented and retrievable by testing batch number, in accordance with the QAPD:

- testing batch reports

- all raw data, including instrument readouts, calculation records, and radioassay QC results

- all instrument calibration reports, as applicable

\section{A.6 Quality Characteristics Assessment}

Per 40 CFR §194.22(c), there are five "quality characteristics" that have to be assessed. These quality characteristics and the method by which they are assessed are described in the following sections.

\section{A.6.1 Data Accuracy}

Per 40 CFR §194.22(c)(1), Data Accuracy is defined as "the degree to which data agree with an acceptable reference or true value." For NDA methods, this quality characteristic is met and maintained as described in section A.3. For RC methods, this quality characteristic is met and maintained through the requirements specified in table A-4. 3 in section A.4.3.

\section{A.6.2 Data Precision}

Per 40 CFR §194.22(c)(2), Data Precision is defined as "a measure of the mutual agreement between comparable data gathered or developed under similar conditions expressed in terms of standard deviation." For NDA methods, this quality characteristic is met and maintained as described in section A.3. For RC methods, this quality characteristic is met and maintained through the requirements specified in table A-4. 3 in section A.4.3.

\section{A.6.3 Data Representativeness}

Per 40 CFR §194.22(c)(3), Data Representativeness is defined as "the degree to which data can accurately and precisely represent a characteristic of a population, a parameter, variations at a sampling point, or environmental conditions." For NDA and RC methods, this quality characteristic for the waste stream is met and maintained through $100 \%$ measurement confirmation on a payload container basis. For NDA, since the entire waste container is subjected to measurement, representativeness pertaining to 
the actual measurement is not applicable. However, since a sample is physically removed from the container for $\mathrm{RC}$ measurements and must be representative of the waste within the container, section A.4.3 provides the criteria for representativeness for the actual sample itself.

\section{A.6.4 Data Completeness}

Per 40 CFR §194.22(c)(4), Data Completeness is defined as "a measure of the amount of valid data obtained compared to the amount that was expected." For NDA methods, this quality characteristic is met and maintained by requiring $100 \%$ valid results. Any results indicating the NDA measurement was invalid require re-measurement. For RC methods, this quality characteristic is met and maintained through the requirements specified in section A.4.3.

\section{A.6.5 Data Comparability}

Per 40 CFR §194.22(c)(5), Data Comparability is defined as "a measure of confidence with which one data set can be compared to another." For NDA and RC methods, this quality characteristic is addressed by ensuring that all data are produced under the same system of controls. These controls apply to all aspects of the data generation process, including: procurement of analytical instruments; calibration and operation of assay equipment according to industry standards; preparation and use of standardized instrument and data review procedures; and, training of equipment operators and technical/data review personnel to the QAPD, as specified in section A.4.1. All NDA and $\mathrm{RC}$ systems and methods are approved by CBFO prior to use in generating waste characterization data. Additionally, comparison of measured data with AK derived or based values, as applicable, provides a means to assess comparability on a waste stream basis. Although no specific confidence level is specified, these controls provide comparability among all data generated under this program. Sites using radioassay systems shall participate in measurement comparison programs as specified in section A.4.1. 


\section{References}

A1. U.S. Nuclear Regulatory Commission. Peer Review for High-Level Nuclear Waste Repositories, NUREG-1297, Washington D.C., Office of Nuclear Material Safety and Safeguards, U.S. Nuclear Regulatory Commission.

A2. U.S. Department of Energy. Quality Assurance Program Document. DOE/CBFO-94-1012. Carlsbad, New Mexico, Carlsbad Field Office, U.S. Department of Energy. (http://www.wipp.ws/library/qapd/qapd.pdf)

A3. Currie, Lloyd A., 1968. Limits for Qualitative Detection and Quantitative Determination. Anal.Chem. 40: 586-93.

A4. EPA, 1980. Upgrading Environmental Radiation Data. EPA 520/1-80-012, Washington D.C., Office of Radiation Programs, U. S. Environmental Protection Agency.

A5. K. C. Smith, R. A. Stroud, K. L. Coop, and J. F. Bresson. 1998. Total Measurement Uncertainty Assessment for Transuranic Waste Shipments to the Waste Isolation Pilot Plant. Proceedings of the 6th Nondestructive Assay Waste Characterization Conference, Salt Lake City, Utah, Nov. 17-19, 1998, pp.21-37.

A6. K. L. Coop, J. F. Bresson, M. E. Doherty, B. M. Gillespie, and D. R. Davidson. Standardized Total Measurement Uncertainty Reporting for WIPP. Nondestructive Assay Interface Working Group, Salt Lake City, Utah, May 22, 2000.

A7. U.S. Department of Energy. Performance Demonstration Program Plan for Nondestructive Assay of Boxed Wastes for the TRU Waste Characterization Program. DOE/CBFO-01-1006. Carlsbad, New Mexico, Carlsbad Field Office, U.S. Department of Energy. (http://www.wipp.ws/library/pdp/DOE-CBFO-01-1006Rev0.pdf)

A8. American Society for Testing and Materials. Standard Guide for Selection, Training and Qualification of Nondestructive Assay (NDA) Personnel, ASTM C1490, Annual Book of ASTM Standards, Philadelphia, Pennsylvania, American Society for Testing and Materials.

A9. American National Standards Institute. Radiometric Calorimeters - Measurement Control Program, ANSI N15.54, American National Standards Institute, Inc., 1430 Broadway, New York, NY 10018.

A10. U.S. Department of Energy. Performance Demonstration Program Plan for Nondestructive Assay of Drummed Wastes for the TRU Waste Characterization 
Program. DOE/CBFO-01-1005. Carlsbad, New Mexico, Carlsbad Field Office, U.S. Department of Energy. (http://www.wipp.ws/library/pdp/DOE-CBFO-01-1005Rev0.1.pdf)

A11. American Society for Testing and Materials. Standard Test Method for Determination of Plutonium Isotopic Composition by Gamma-Ray Spectrometry. ASTM C1030-95, Annual Book of ASTM Standards, Philadelphia, Pennsylvania, American Society for Testing and Materials.

A12. American Society for Testing and Materials. Standard Test Method for Nondestructive Assay of Nuclear Material in Scrap and Waste by Passive-Active Neutron Counting Using a 252Cf Shuffler. ASTM C1316-95, Philadelphia, Pennsylvania, American Society for Testing and Materials.

A13. American Society for Testing and Materials. Standard Test Method for Nondestructive Assay of Special Nuclear Material in Low Density Scrap and Waste by Segmented Passive Gamma-Ray Scanning. ASTM C1133-96, Annual Book of ASTM Standards, Philadelphia, Pennsylvania, American Society for Testing and Materials.

A14. American Society for Testing and Materials. Standard Test Method for Nondestructive Assay of Plutonium, Tritium and 241 Am by Calorimetric Assay. ASTM C1458-00, Annual Book of ASTM Standards, Philadelphia, Pennsylvania, American Society for Testing and Materials.

A15. American National Standards Institute. Nondestructive Assay Measurement Control and Assurance, ANSI N15.36. American National Standards Institute, Inc., 1430 Broadway, New York, NY 10018

A16. U.S. Nuclear Regulatory Commission. 1984. Nondestructive Assay of Special Nuclear Material Contained in Scrap and Waste. Regulatory Guide 5.11, Washington, DC, Office of Nuclear Regulatory Research, U.S. Nuclear Regulatory Commission.

A17. American National Standards Institute. Plutonium-Bearing Solids Calibration Techniques for Calorimetric Assay. ANSI N15.22-1987, American National Standards Institute, Inc., 1430 Broadway, New York, NY 10018. 


\section{APPENDIX B}

\section{${ }^{239} \mathrm{Pu}$ Equivalent Activity}


The concept of ${ }^{239} \mathrm{Pu}$ equivalent activity (PE-Ci) is intended to eliminate the dependency of radiological analyses on specific knowledge of the radionuclide composition of a TRU waste stream. A unique radionuclide composition and/or distribution is associated with most TRU waste streams at each site. By normalizing all radionuclides to a common radiotoxic hazard index, radiological analyses that are essentially independent of these variations can be conducted for the WIPP facility. ${ }^{239} \mathrm{Pu}$, as a common component of most defense TRU wastes, was selected as the radionuclide to which the radiotoxic hazard of other TRU radionuclides could be indexed.

Modeled operational releases from the WIPP facility, including both routine and accidentrelated, are airborne. There are no known significant liquid release pathways during the operational phase of the facility. This, and the fact that TRU radionuclides primarily represent inhalation hazards, allows a valid relationship to be established, which normalizes the inhalation hazard of a TRU radionuclide to that of ${ }^{239} \mathrm{Pu}$ for the purpose of the WIPP radiological analyses. In effect, the radiological dose consequences of an airborne release of a quantity of TRU radioactivity with a known radionuclide distribution will be essentially identical to that of a release of that material expressed in terms of a quantity of ${ }^{239} \mathrm{Pu}$. To obtain this correlation, the 50 -year effective whole-body dose commitment or dose conversion factor for a unit intake of each radionuclide will be used.

For a known radioactivity quantity and radionuclide distribution, the ${ }^{239} \mathrm{Pu}$ equivalent activity is determined using radionuclide-specific weighting factors. The ${ }^{239} \mathrm{Pu}$ equivalent activity (AM) can be characterized by

$$
\mathrm{AM}=\sum_{i=1}^{K} A_{i} / W F_{i}
$$

where $K$ is the number of $\mathrm{TRU}^{2}$ radionuclides, $A_{i}$ is the activity of radionuclide $i$, and $W F_{i}$ is the PE-Ci weighting factor for radionuclide $i$.

$W F_{i}$ is further defined as the ratio

$$
W F_{i}=E_{o} / E_{i}
$$

where $E_{o}(\mathrm{rem} / \mu \mathrm{Ci})$ is the 50 -year effective whole-body dose commitment due to the inhalation of ${ }^{239} \mathrm{Pu}$ particulates with a $1.0 \mu \mathrm{m}$ activity median aerodynamic diameter (AMAD) and a weekly pulmonary clearance class, and $E_{i}(\mathrm{rem} / \mu \mathrm{Ci})$ is the 50 -year effective whole-body dose commitment due to the inhalation of radionuclide (I) particulates with a $1.0 \mu \mathrm{m}$ activity median aerodynamic diameter and the pulmonary clearance class resulting in the highest 50-year effective whole-body dose commitment.

${ }^{2}$ TRU as designated in this equation refers to any radionuclide with an atomic number greater than 92 and including ${ }^{233} \mathrm{U}$. 
Weighting factors calculated in this manner are presented in table B-1 for radionuclides typically present in $\mathrm{CH}$-TRU waste. If other TRU radionuclides are determined to be present in the payload container, their weighting factors can be obtained from the values of $E_{o}$ and $E_{i}$ contained in DOE/EH-0071 (reference B1).

Table B-1

PE-Ci Weighting Factors for Selected Radionuclides

\begin{tabular}{|c|c|c|}
\hline Radionuclide & $\begin{array}{c}\text { Pulmonary Clearance } \\
\text { Class }^{{ }^{2}}\end{array}$ & Weighting Factor \\
\hline${ }^{233} \mathrm{U}$ & $\mathrm{Y}$ & 3.9 \\
\hline${ }^{237} \mathrm{~Np}$ & $\mathrm{~W}$ & 1.0 \\
\hline${ }^{236} \mathrm{Pu}$ & $\mathrm{W}$ & 3.2 \\
\hline${ }^{238} \mathrm{Pu}$ & $\mathrm{W}$ & 1.1 \\
\hline${ }^{239} \mathrm{Pu}$ & $\mathrm{W}$ & 1.0 \\
\hline${ }^{240} \mathrm{Pu}$ & $\mathrm{W}$ & 1.0 \\
\hline${ }^{241} \mathrm{Pu}$ & $\mathrm{W}$ & 51.0 \\
\hline${ }^{242} \mathrm{Pu}$ & $\mathrm{W}$ & 1.1 \\
\hline${ }^{241} \mathrm{Am}$ & $\mathrm{W}$ & 1.0 \\
\hline${ }^{243} \mathrm{Am}$ & $\mathrm{W}$ & 1.0 \\
\hline${ }^{242} \mathrm{Cm}$ & $\mathrm{W}$ & 30.0 \\
\hline${ }^{244} \mathrm{Cm}$ & $\mathrm{W}$ & 1.9 \\
\hline${ }^{252} \mathrm{Cf}$ & $\mathrm{Y}$ & 3.9 \\
\hline
\end{tabular}

a(W) Weekly, (Y) Yearly

\section{References}

B1. U.S. Department of Energy. Internal Dose Conversion Factors for Calculation of DOSE to the Public. DOE/EH-0071, July 1988. 


\section{APPENDIX C}

\section{Glossary}

$$
\text { C - } 1
$$


Acceptable knowledge (AK) -Knowledge used for waste characterization, which is based on the materials and processes used to generate a waste. Acceptable knowledge includes information about the physical form of the waste, the base materials composing the waste (especially hazardous and radioactive materials), and the process that generated the waste. Aceeptable knowledge is used to define waste streams, assign summary eategories, assign EPA hazardous waste numbers, estimate the weight fraetion of CPR, and estimate isotopie ratios. Any information about the process used to generate waste, material inputs to the process, and the time period during which the waste was generated, as well as data resulting from the analysis of waste, conducted prior to or separate from the waste certification process authorized by EPA's Certification Decision, to show compliance with Condition 3 of the certification decision (appendix A of this part). (40 CFR §194.2 and §194.67)

Activity - A measure of the rate at which a material emits nuclear radiation, usually given in terms of the number of nuclear disintegrations occurring in a given length of time. The common unit of activity is the curie, which amounts to 37 billion $\left(3.7 \times 10^{10}\right)$ disintegrations per second. The International Standard unit of activity is the becquerel and is equal to one disintegration per second.

Administrative controls - Provisions relating to organization and management, procedures, record keeping, assessment, and reporting necessary to ensure the safe operation of the facility.

Atomic energy defense activities - Activities of the Secretary of Energy (and predecessor agencies) performed in whole or in part in carrying out any of the following functions: naval reactors development; weapons activities, including defense inertial confinement fusion; verification and control technology; defense nuclear material production; defense nuclear waste and materials by-product management; defense nuclear materials security investigations; and defense research and development.

Authorization basis - Those aspects of the facility design and operational requirements relied upon by DOE to authorize the operation of nuclear facilities and processes.

Characterization - Sampling, monitoring, and analysis-whether by review of AK, nondestructive examination, NDA, RC, headspace gas analysis, or chemical analysis of the volatile or semi-volatile organic compounds or metals-to identify and quantify the constituents of a waste material.

Chemical compatibility - Assessing the properties of chemicals in a payload container (>1 weight percent); there must be no adverse safety or health hazards produced as a result of any mixtures that occur.

Completeness - The percentage of measurements made which are judged to be valid measurements. The completeness goal is to generate a sufficient amount of valid data 
based on program needs. Valid results for analytical, radioassay, and radiography data are those that were obtained when the laboratory or testing facility demonstrated that the instrumentation and method were in control; that is, that all calibration, verification, interference, and zero matrix checks met acceptance criteria. Valid samples are those collected and submitted for analysis that were representative and met all preservation requirements upon arrival at the laboratory.

Compressed gas - Compressed gases are those materials defined as such by 49 CFR Part 173, Subpart G.

Contact-handled transuranic waste - Transuranic waste with a surface radiation dose equivalent rate not greater than $200 \mathrm{mrem} / \mathrm{h}$.

Contact-handled transuranic waste authorized methods for payload control $(\mathrm{CH}-$ TRAMPAC) - The governing document for shipments in the TRUPACT-II and HalfPACT packagings.

Contact-handled transuranic waste content codes (CH-TRUCON) - The document containing a description of the waste stream, waste form, and package configuration for each waste content code authorized for shipment in the TRUPACT-II and HalfPACT packagings.

Content code - A uniform system applied to waste forms to group those with similar characteristics for purposes of shipment in the TRUPACT-II and HalfPACT packagings.

Corrosive/Corrosivity - A solid waste exhibits corrosivity if a sample of the waste is either aqueous and has a $\mathrm{pH} \leq 2$ or $\geq 12.5$, or it is a liquid and corrodes steel at a rate $>6.35 \mathrm{~mm}(0.250 \mathrm{inch})$ per year at a test temperature of $55^{\circ}\left(130^{\circ} \mathrm{F}\right)$. (40 CFR §261.22)

Curie - A unit of activity equal to 37 billion $\left(3.7 \times 10^{10}\right)$ disintegrations per second.

Disposal - Permanent isolation of TRU waste from the accessible environment with no intent of recovery, whether or not such isolation permits the recovery of such waste (reference 2, section 2, subsection 5).

Dose conversion factor - A numerical factor used in converting radionuclide uptake (curies) in the body to the resultant radiation dose (rem).

Dose equivalent rate - The radiation dose equivalent delivered per unit time (e.g., rem per hour).

Fissile gram equivalent - An isotopic mass of radionuclide normalized to ${ }^{239} \mathrm{Pu}$.

Fissile material - Any material consisting of or containing one or more radionuclides that 
can undergo neutron-induced fission with neutrons of essentially zero kinetic energy (e.g., thermal neutrons) such as ${ }^{233} \mathrm{U},{ }^{235} \mathrm{U}$, and ${ }^{239} \mathrm{Pu}$.

HalfPACT - An NRC-certified Type B transportation packaging used for transportation of $\mathrm{CH}-\mathrm{TRU}$ wastes.

Hazardous waste - Those wastes which are designated hazardous by EPA (or state) regulations. For a detailed description, see 40 CFR § 261.3. Hazardous wastes are listed in 20.4.1 NMAC, subpart II (40 CFR Part 261) and/or exhibit one of the four characteristics in 20.4.1 NMAC, subpart II (40 CFR Part 261) (i.e., ignitability, corrosivity, reactivity, and toxicity).

Headspace - The total contained volume of a container minus the volume occupied by the waste material.

Headspace gas - The gas within the headspace of a container.

Lower Limit of Detection - The level of radioactivity which, if present, will yield a measured value greater than the critical limit with a $95 \%$ probability. The critical limit is defined as that value which measurements of the background will exceed with a $5 \%$ probability.

Machine-compacted waste - Waste whose volume has been reduced using a mechanical process.

Overpack - A container put around another container (reference 17, Glossary of Terms).

Package - (1) A packaging plus its contents. (2) The reusable Type B shipping container (i.e., TRUPACT-II and HalfPACT) loaded with TRU waste payload containers, which has been prepared for shipment in accordance with the package QA program. (3) In the regulations governing the transportation of radioactive materials, the packaging, together with its radioactive contents, as presented for transport.

Packaging - The reusable Type B shipping container for transport of TRU waste payload containers (i.e., TRUPACT-II and HalfPACT).

Packaging quality assurance program - A site-specific document that defines the quality assurance and quality control activities applicable to usage of the NRC-approved packaging. This program shall meet the requirements of 10 CFR Part 71, Subpart H.

Payload container - The outermost container (i.e., drum, SWB, or TDOP) for TRU waste material that is placed in a reusable Type B shipping container (i.e., TRUPACT-II and HalfPACT) for transport. 
Payload assembly - An assembly of payload containers qualified for transport in a TRUPACT-II or HalfPACT.

Pipe overpack - A packaging configuration consisting of a vented cylindrical pipe component surrounded by dunnage within a vented 55-gallon drum with a rigid polyethylene liner and vented lid.

Plutonium equivalent activity - An equivalent radiotoxic hazard of a radionuclide normalized to ${ }^{239} \mathrm{Pu}$.

Precision - A measure of mutual agreement among individual measurements of the same property made under prescribed similar conditions; often expressed as a standard deviation or relative percent difference.

Pyrophoric - Materials that may ignite spontaneously in air or that emit sparks when scratched or struck, especially with materials such as steel. A flammable solid that, under transport conditions, might cause fires through friction or retained heat or that can be ignited readily and, when ignited, burns vigorously and persistently so as to create a serious transportation hazard. Included in the pyrophoric definition are spontaneously combustible materials, water reactive materials, and oxidizers. Examples of nonradioactive pyrophorics are organic peroxides, sodium metal, and chlorates.

Radioassay - Methods used to identify and quantify radionuclides in TRU waste. Radioassay includes NDA and RC.

Radiography - A nondestructive testing method that uses $X$-rays to inspect and determine the physical form of waste.

Radionuclide - A nuclide that emits radiation by spontaneous transformation.

Shipper - A TRU waste site that releases a TRUPACT-II or HalfPACT to a carrier for shipment.

Shipping category - A shipping category is defined by the following parameters: chemical composition of the waste (waste type), gas generation potential of the waste material type (quantified by the g-value for hydrogen), and gas release resistance (type of payload container and type and maximum number of confinement layers used).

Sites - Department of Energy TRU waste generator/storage sites.

Standard waste box - A metal payload container authorized for use within the TRUPACT-II and HalfPACT packaging, that has been tested by DOE to meet DOT Specification 7A Type A requirements. 
Summary category group - Used to segregate TRU-mixed wastes into broad groups having similar physical forms. The summary category groups include homogeneous solids (S3000) that are at least 50 percent by volume solid process residues, soil/gravel (S4000) that is at least 50 percent by volume soil/gravel, and debris (S5000) that is at least 50 percent by volume materials that meet the criteria specified in 20.4.1.800 New Mexico Administrative Code (incorporating 40 CFR §268.2(g)). If a waste does not include at least 50 percent of any given category by volume, then the summary category group assigned shall be the same as that constituting the greatest volume of waste for that waste stream. (Reference 6, attachment B)

Ten-drum overpack - A metal payload container authorized for use within the TRUPACT-II packaging, that has been tested by DOE to meet DOT Specification 7A Type A requirements.

Test Category - Payload containers that do not meet the analytical category decay heat limits or whose concentration of flammable VOCs in the headspace exceeds 500 ppm are classified as test category. (CH-TRAMPAC, section 5.2.2.3)

Trace chemicals/materials - Chemicals/materials that occur individually in the waste in quantities less than 1 weight percent. The total quantity of chemicals/materials not listed as allowed materials for a given waste material type in any payload container is restricted to less than 5 weight percent. (CH-TRAMPAC, section 4.3.1)

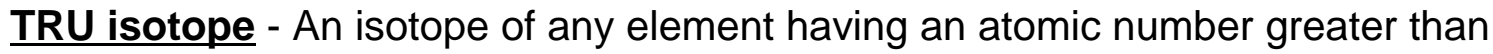
uranium (i.e., 92).

TRU waste - Waste containing more than $100 \mathrm{nCi}$ of alpha-emitting TRU isotopes per gram of waste, with half-lives greater than 20 years, except for (1) high-level radioactive waste, (2) waste that the Secretary has determined, with the concurrence of the Administrator, does not need the degree of isolation required by the disposal regulations, or (3) waste that the NRC has approved for disposal on a case-by-case basis in accordance with 10 CFR Part 61. (Land Withdrawal Act, section 2, subsection 18)

TRU-mixed waste - TRU waste that is also a hazardous waste as defined by the Hazardous Waste Act and 20.4.1.200 NMAC (incorporating 40 CFR § 261.3). (Hazardous Waste Facility Permit, module I, section I.D.6)

TRUPACT-II - An NRC-certified Type B transportation packaging used for transportation of $\mathrm{CH}-\mathrm{TRU}$ wastes.

Verification - The act of authenticating or formally asserting the truth that a process, item, data set, or service is, in fact, that which is claimed. Data verification is the process used to confirm that all review and validation procedures have been completed. 
Volatile organic compounds - For the purposes of the TRU waste program, those RCRA-regulated VOCs listed in the WIPP WAP and any additional compounds tentatively identified by VOC analytical procedures used to satisfy program requirements (i.e., any compound containing carbon and hydrogen with any other element that has a vapor pressure of $77.6 \mathrm{~mL}$ of mercury (1.5 psia) or greater under actual storage conditions).

Waste acceptance criteria - Constraints (limits) on the physical, chemical, and radiological properties of TRU waste and its packaging as determined by WIPP's authorization basis requirements. TRU waste will not be approved for shipment to and disposal at the WIPP until it has been certified as meeting these criteria. Waste acceptance criteria ensure that $\mathrm{CH}$-TRU waste is managed and disposed of in a manner that protects human health and safety and the environment.

Waste analysis plan - The waste analysis plan includes test methods, details of planned waste sampling and analysis, a description of the waste shipment screening and verification process, and a description of the QA/QC program. Sites are required to implement the applicable requirements of the WIPP WAP. (Hazardous Waste Facility Permit, attachment B)

Waste characterization - The process of determining that TRU waste meets the requirements of the $\mathrm{CH}-\mathrm{WAC}$ by the acceptable performance of the activities defined by CBFO-approved site-specific plans.

Waste certification - Formal and documented declaration by sites that waste has been characterized and meets the requirements of the WIPP CH-WAC.

Waste matrix code - A DOE-developed coding system for grouping waste streams that have similar matrix constituents, especially for treatment objectives. This coding system allows waste streams within the DOE TRU waste system that have similar physical and chemical waste form properties to be categorized together. (Transuranic Waste Baseline Inventory Report, DOE/CAO-95-1121)

Waste stream - A waste stream is waste material generated from a single process or from an activity which is similar in material, physical form, and hazardous constituents (Hazardous Waste Facility Permit, attachment B). 


\section{APPENDIX D}

\section{Payload Container Integrity Checklist}

$$
\text { D - } 1
$$


The operator is to visually examine $100 \%$ of the payload container exterior to determine if the payload container meets the criteria of section 3.2.1. At a minimum, sites shall incorporate the questions and criteria contained in the following checklist into applicable site procedures. This payload container inspection shall be performed and documented as a part of the TRUPACT-II and HalfPACT loading process. Any YES answer on the inspection checklist will result in the operator discontinuing the inspection, marking the payload container as unacceptable for shipment, and removal of the payload container from the shippable inventory. Before the rejected container can be shipped, it must undergo appropriate corrective actions (e.g., evaluation, repackaging, overpacking, etc.), as applicable. All containers must have an acceptable and complete inspection checklist documenting that it meets the DOT 7A criteria.

\begin{tabular}{|c|c|c|c|c|}
\hline \multicolumn{2}{|r|}{ CONTAINER EXAMINATION } & \multirow{2}{*}{\begin{tabular}{l}
\multicolumn{1}{c}{ DISCUSSION OF CRITERIA } \\
Obviously degraded means clearly visible and \\
potentially significant defects in the payload \\
container or payload container surface.
\end{tabular}} & \multicolumn{2}{|c|}{ COMPLIANCE } \\
\hline 1. & $\begin{array}{l}\text { Is the payload container } \\
\text { obviously degraded? }\end{array}$ & & YES & NO \\
\hline 2. & $\begin{array}{l}\text { Is there evidence that the } \\
\text { payload container is, or has } \\
\text { been, pressurized? }\end{array}$ & $\begin{array}{l}\text { Pressurization can be indicated by a fairly } \\
\text { uniform expansion of the sidewalls, bottom or } \\
\text { top. Past pressurization can be indicated by a } \\
\text { notable outward deflection of the bottom or top. } \\
\text { Verify that the drum is not warped. }\end{array}$ & YES & NO \\
\hline 3. & $\begin{array}{l}\text { Is there any potentially } \\
\text { significant rust or corrosion } \\
\text { such that wall thinning, pin } \\
\text { holes, or breaches are likely or } \\
\text { the load bearing capacity is } \\
\text { suspect? }\end{array}$ & $\begin{array}{l}\text { Rust shall be assessed in terms of its type, } \\
\text { extent, and location. Pitting, pocking, flaking, or } \\
\text { dark coloration characterizes potentially } \\
\text { significant rust or corrosion. This includes the } \\
\text { extent of the payload container surface area } \\
\text { covered, thickness, and, if it occurs in large } \\
\text { flakes or built-up (caked) areas. Rusted payload } \\
\text { containers may not be accepted if: } \\
\text { Rust is present in caked layers or } \\
\text { deposits } \\
\text { Rust is present in the form of deep } \\
\text { metal flaking, or built-up areas of } \\
\text { corrosion products } \\
\text { In addition, the location of rust should be noted; } \\
\text { for example on a drum: top lid; filter region; } \\
\text { locking chine; top one-third, above the second } \\
\text { rolling hoop; middle one-third, between the first } \\
\text { and second rolling hoops; bottom one-third, } \\
\text { below the second rolling hoop; and on the } \\
\text { bottom. } \\
\text { Payload containers may still be considered } \\
\text { acceptable if the signs of rust show up as: } \\
\text { Some discoloration on the payload } \\
\text { container } \\
\text { If rubbed would produce fine grit or dust } \\
\text { or minor flaking (such that wall thinning } \\
\text { does not occur) }\end{array}$ & YES & NO \\
\hline
\end{tabular}




\begin{tabular}{|c|c|c|c|c|}
\hline \multicolumn{2}{|r|}{ CONTAINER EXAMINATION } & \multirow{2}{*}{$\begin{array}{l}\text { DISCUSSION OF CRITERIA } \\
\text { Wall thinning, pin holes, and breaches can be a } \\
\text { result of rust/corrosion (see discussion for } \# 3 \text { ). }\end{array}$} & \multicolumn{2}{|c|}{ COMPLIANCE } \\
\hline 4. & $\begin{array}{l}\text { Are any of the following } \\
\text { apparent? } \\
\begin{array}{l}\text { - } \quad \text { wall thinning } \\
\text { - } \quad \text { pin holes } \\
\text { breaches }\end{array}\end{array}$ & & YES & NO \\
\hline 5. & $\begin{array}{l}\text { Are there any split seams, } \\
\text { tears, obvious holes, punctures } \\
\text { (of any size), creases, broken } \\
\text { welds, or cracks? }\end{array}$ & $\begin{array}{l}\text { Payload containers with obvious leaks, holes or } \\
\text { openings, cracks, deep crevices, creases, tears, } \\
\text { broken welds, sharp edges or pits, are either } \\
\text { breached or on the verge of being breached. } \\
\text { Verify that there is no warpage that could cause } \\
\text { the container to be unstable or prevent it from } \\
\text { fitting properly in the TRUPACT-II or HalfPACT, } \\
\text { as applicable. }\end{array}$ & YES & $\mathrm{NO}$ \\
\hline 6. & $\begin{array}{l}\text { Is the load-bearing capacity } \\
\text { suspect? }\end{array}$ & $\begin{array}{l}\text { The load-bearing capacity could be reduced for } \\
\text { excessive rust (see discussion for \#3), wall } \\
\text { thinning (see discussion for \#4), breaches, } \\
\text { cracks, creases, broken welds, etc. (see } \\
\text { discussion for \#5). }\end{array}$ & YES & $\mathrm{NO}$ \\
\hline 7. & $\begin{array}{l}\text { Is the payload container } \\
\text { improperly closed? }\end{array}$ & $\begin{array}{l}\text { Inspect the fastener and fastener ring (chine) if } \\
\text { applicable for damage or excessive corrosion. } \\
\text { Check the alignment of the fastener to ensure } \\
\text { that it is in firm contact around the entire lid and } \\
\text { the payload container will not open during } \\
\text { transportation. }\end{array}$ & YES & NO \\
\hline 8. & $\begin{array}{l}\text { Are there any dents, scrapes, } \\
\text { or scratches that make the } \\
\text { payload container's structural } \\
\text { integrity questionable or } \\
\text { prevent the top and bottom } \\
\text { surfaces from being parallel? }\end{array}$ & $\begin{array}{l}\text { Deep gouges, scratches, or abrasions over wide } \\
\text { areas are not acceptable. If top and bottom } \\
\text { surfaces are not parallel, this would indicate that } \\
\text { the container is warped. Dents should be less } \\
\text { than } 1 / 4 \text { inch deep by } 3 \text { inches long and between } \\
1 / 2 \text { inch to } 6 \text { inches wide. All other dents must be } \\
\text { examined to determine impact of structural } \\
\text { integrity. }\end{array}$ & YES & NO \\
\hline 9. & $\begin{array}{l}\text { Is there discoloration which } \\
\text { would indicate leakage or other } \\
\text { evidence of leakage of material } \\
\text { from the payload container? }\end{array}$ & $\begin{array}{l}\text { Examine the payload container regions near } \\
\text { vents, top lid fittings, bottom fittings, welds, } \\
\text { seams and intersections of one or more metal } \\
\text { sheets or plates. Payload containers must be } \\
\text { rejected if evidence of leakage is present. }\end{array}$ & YES & $\mathrm{NO}$ \\
\hline
\end{tabular}




\begin{tabular}{|c|c|c|c|c|}
\hline \multicolumn{2}{|c|}{ CONTAINER EXAMINATION } & \multirow[b]{2}{*}{$\begin{array}{l}\text { DISCUSSION OF CRITERIA } \\
\text { For the purposes of this examination, bulging is } \\
\text { indicated by: } \\
\text { A fairly uniform expansion of the } \\
\text { sidewalls, bottom, or top (e.g., in the } \\
\text { case of a drum, either the top or bottom } \\
\text { surface protrudes beyond the planar } \\
\text { surface of the top or bottom ring, } \\
\text { A protrusion of the side wall (e.g., in the } \\
\text { case of a drum, beyond a line } \\
\text { connecting the peaks of the } \\
\text { surrounding rolling hoops or a line } \\
\text { between a surrounding rolling hoop and } \\
\text { the bottom or top ring), or } \\
\text { Expansion of the sidewall (e.g., in the } \\
\text { case of a drum, such that it deforms }\end{array}$} & \multicolumn{2}{|c|}{ COMPLIANCE } \\
\hline 10. & $\begin{array}{l}\text { Is the payload container } \\
\text { bulged? }\end{array}$ & & YES & NO \\
\hline
\end{tabular}

\section{References}

INEEL Engineering Design File "Waste Container Integrity Evaluation for Storage", EDFRWMC-705, September 25, 1996. Idaho National Engineering and Environmental Laboratory, Idaho Falls, ID.

Title 49 CFR Part 173, Subpart 475. "Quality Control Requirements Prior to Each Shipment of Class 7 (Radioactive) Materials." Code of Federal Regulations, Washington, D.C., Office of the Federal Register, National Archives and Records Administration.

DOE/RL-96-57, Section 2.5.5. "Test \& Evaluation Document for the U. S. Department of Transportation Specification 7A type to Packaging. (Formerly WHC-EP-0558). 


\section{APPENDIX E}

\section{Payload Management of} TRU Alpha Activity Concentration 


\section{E.1 Scope}

The policies and methods for the management of TRU alpha activity concentration within each TRU waste payload container disposed of at WIPP are set out below. They are based on the definition of TRU waste in the Waste Isolation Pilot Plant (WIPP) Land Withdrawal Act (LWA), Public Law 102-579. The LWA defines TRU waste as:

"...waste containing more than 100 nanocuries of alpha emitting transuranic isotopes per gram of waste, with half lives greater than 20 years..." (Sec. 2(18))

This appendix pertains specifically to the payload management of TRU alpha activity concentration of waste containers selected for overpacking.

\section{E.2 Policies}

The National TRU Waste Program has established the following policies for managing TRU alpha activity concentration in compliance with the LWA: (References E1, E2, and E3)

- $\quad$ The TRU alpha activity concentration limit for TRU waste (>100 nCi/g) applies to the TRU waste stream as a whole.

- Waste containers belonging to a TRU waste stream may vary in their TRU alpha activity concentration, some containing $>100 \mathrm{nCi} / \mathrm{g}$ and some containing $\leq 100 \mathrm{nCi} / \mathrm{g}$. Using process knowledge in combination with radioassay measurements to determine the presence of transuranic isotopes within the waste stream, generator sites define a TRU waste stream based on its potential to include waste containers with a TRU alpha activity concentration in excess of $100 \mathrm{nCi} / \mathrm{g}$.

- Waste containers belonging to the same TRU waste stream may be overpacked into a payload container (e.g., SWB or TDOP) provided the TRU alpha activity concentration of the payload container exceeds 100 $\mathrm{nCi} / \mathrm{g}$.

\section{E.3 Prerequisites for Implementation}

- $\quad$ Each waste container selected for payload management must be part of the TRU waste stream identified in the AK summary report for that waste stream. (References E2 and E3)

- $\quad$ Sites shall submit to the CBFO, for its review and approval, applicable plans and procedures for making TRU waste determinations based on 
payload management practices that involve the overpacking of waste containers. (Reference E2)

- $\quad$ CBFO will notify EPA of sites seeking such authorization prior to CBFO's approval of a site to manage TRU alpha activity concentration using payload management. The WIPP will not accept payload managed waste for disposal until EPA has received notice. (Reference E3)

\section{E.4 Implementation and Practice}

- $\quad$ Each TRU waste stream selected for payload management must include in its acceptable knowledge summary report an estimate of the total waste volume and the percentage of the waste volume that is above and below $100 \mathrm{nCi} / \mathrm{g}$. (It should be noted that this information, although based on the best available AK information, is preliminary and subject to the performance of WIPP certified NDA measurements and cannot and will not be used as a measure of AK accuracy.) (Reference E3)

- $\quad$ Each waste container selected for payload management must contain at least one TRU isotope (e.g., ${ }^{238} \mathrm{Pu},{ }^{239} \mathrm{Pu},{ }^{240} \mathrm{Pu}$, ${ }^{242} \mathrm{Pu}$, etc.) whose activity exceeds the LLD of the radioassay system used to characterize the waste. (References E2 and E3) The applicability of LLD will vary from system to system and may be on a container basis. Sections 3.3.1 and A.3 of this document provide the applicable requirements for determining and reporting LLDs.

- $\quad$ Each waste container selected for payload management may only be overpacked into a payload container (e.g., SWB or TDOP) with other waste containers from the same TRU waste stream. (Reference E4)

- $\quad$ The TRU alpha activity concentration of the payload container is determined according to section 3.3.3 of this document.

\section{E.5 References}

E1. Public Law 102-579, 106 Stat.4777, 1992 (as amended by Public Law 104-201, 1996). Waste Isolation Pilot Plant Land Withdrawal Act.

E2. Letter to Mr. Frank Marcinowski (Director, Office of Radiation and Indoor Air, U.S. Environmental Protection Agency) from Dr. Ines R. Triay (Manager, Carlsbad Field Office, U.S. Department of Energy), August 4, 2003.

$$
E-3
$$


E3. Letter to Dr. Ines R. Triay (Manager, Carlsbad Field Office, U.S. Department of Energy) from Mr. Frank Marcinowski (Director, Office of Radiation and Indoor Air, U.S. Environmental Protection Agency), August 8, 2003.

E4. Waste Isolation Pilot Plant Hazardous Waste Facility Permit, NM4890139088TSDF, New Mexico Environment Department, Santa Fe, New Mexico. 